Article

\title{
Assessing Spatio-Temporal Variability of Wildfires and their Impact on Sub-Saharan Ecosystems and Air Quality Using Multisource Remotely Sensed Data and Trend Analysis
}

\author{
Mahlatse Kganyago $1, *(1)$ and Lerato Shikwambana $2,3, *(1)$ \\ 1 Earth Observation, South African National Space Agency, The Enterprise Building, Mark Shuttleworth \\ Street, Pretoria 0001, South Africa \\ 2 Space Science Directorate, South African National Space Agency, Hermanus 7200, South Africa \\ 3 School of Chemistry and Physics, University of KwaZulu-Natal, Private Bag X54001, Durban 4000, South Africa \\ * Correspondence: mkganyago@sansa.org.za (M.K.); lshikwambana@gmail.com (L.S.); \\ Tel.: +27-12-844-0424 (M.K.); +27-28-312-1196 (L.S.)
}

Received: 17 October 2019; Accepted: 25 November 2019; Published: 30 November 2019

check for updates

\begin{abstract}
Globally, wildfires are considered the most commonly occurring disasters, resulting from natural and anthropogenic ignition sources. Wildfires consist of burning standing biomass at erratic degrees of intensity, severity, and frequency. Consequently, wildfires generate large amounts of smoke and other toxic pollutants that have devastating impacts on ambient air quality and human health. There is, therefore, a need for a comprehensive study that characterizes land-atmosphere interactions with regard to wildfires, critical for understanding the interrelated and multidimensional impacts of wildfires. Current studies have a limited scope and a narrow focus, usually only focusing on one aspect of wildfire impacts, such as air quality without simultaneously considering the impacts on land surface changes and vice versa. In this study, we use several multisource data to determine the spatial distribution, frequency, disturbance characteristics of and variability and distribution of pollutants emitted by wildfires. The specific objectives were to (1) study the sources of wildfires and the period they are prevalent in sub-Saharan Africa over a 9 year period, i.e., 2007-2016, (2) estimate the seasonal disturbance of wildfires on various vegetation types, (3) determine the spatial distribution of black carbon (BC), carbon monoxide (CO) and smoke, and (4) determine the vertical height distribution of smoke. The results show largest burned areas in December-January-February (DJF), June-July-August (JJA) and September-October-November (SON) seasons, and reciprocal high emissions of BC, CO, and smoke, as observed by Modern-Era Retrospective Analysis for Research and Applications version 2 (MERRA-2) and Cloud-Aerosol Lidar and Infrared Pathfinder Satellite Observations (CALIPSO). In addition, the results reveal an increasing trend in the magnitude of BC, and $\mathrm{CO}$ concentration driven by meteorological conditions such as low precipitation, low relative humidity, and low latent heat flux. Overall, this study demonstrates the value of multisource remotely sensed data in characterising long-term wildfire patterns and associated emissions. The results in this study are critical for informing better regional fire management and air quality control strategies to preserve endangered species and habitats, promote sustainable land management, and reduce greenhouse gases (GHG) emissions.
\end{abstract}

Keywords: burned area; wildfires; smoke; biomass burning; MODIS; CALIPSO; ESA CCI-LC 


\section{Introduction}

Wildfires are common in many parts of the world, igniting either naturally by lightning or intentionally by anthropogenic activities such as grassland management, deforestation and "slash and burn" agricultural practices. Although wildfires are an integral part of many terrestrial ecosystems, their frequency, intensity, and extent may be detrimental to endangered and threatened ecosystems and their resilience. For example, studies at a global scale show that wildfires led to approximately 400 million hectares (ha) of burned land area, causing destruction of property, biodiversity, ecosystems and associated services in their path [1,2]. Thus, information on fire frequency, intensity and burned area (BA) is critical for understanding and alleviating the environmental, atmospheric and socio-economic impacts of wildfires [3]. Specifically, BA is considered the single most important information for addressing global mandates that seek to reduce fire emissions, such as the Kyoto Protocol, the Paris Agreement, United Nations Sendai Framework on Disaster Risk Reduction 2015-2030, and the Sustainable Development Goals (SDGs), and is a critical input to atmospheric and climate change modelling [4].

Fortunately, BA detection and mapping is well established and has been studied since the dawn of satellite imagery [5] with most recent studies focusing on (a) the development and improvement of detection and mapping techniques [6-8], (b) enhancement of existing global products both in detection accuracy and spatial detail $[9,10]$ and (c) the inter-comparison and validation in different environmental settings and regions [11]. Additionally, the availability of operational satellite-based products, such as land cover, temperature, rainfall, tree cover, etc., provide prospects for assessing and quantifying the impact of wildfires on the ecosystems and biodiversity. However, only a few studies [12-14] have exploited these products for this purpose. Using GLOBCOVER, the Vegetation Continuous Field (VCF), Moderate Resolution Imaging Spectroradiometer (MODIS) Fire Radiative Power (FRP) and the Tropical Rainfall Measuring Mission (TRMM) datasets, Cardozo, Shimabukuro, Pereira and Silva [12] found that biomass of broadleaved evergreen or semi-deciduous forest were mostly burned, attributed to grassland management practices, agricultural land clearing and the deforestation of the Amazon tropical rainforest.

Alarmingly and despite devastating ecological impacts, wildfires also emit approximately $2 \mathrm{Pg}$ of carbon into the atmosphere, thus affecting the atmosphere's chemical composition, visibility, climate and air quality [15-17]. The burning and combustion of vegetation biomass significantly increase the global atmospheric load of trace gases and aerosols such as smoke, which impacts on air quality, the earth's radiation budget and visibility $[18,19]$. In particular, smoke aerosols perturb regional and global radiation budgets through their light-scattering effects and influences on cloud microphysical processes [20]. In addition, smoke aerosols have been linked to illnesses in human populations [21]. This is not surprising since smoke emissions contain mainly carbon monoxide (CO) and black carbon (BC), which can be detrimental when inhaled by exposed populations depending on particle sizes. For example, BC particle sizes that are between $0.1 \mu \mathrm{m}$ to $0.25 \mu \mathrm{m}$ (i.e., ultrafine to fine) can be more harmful to human health than larger particles since they tend to accumulate in the alveolar region of the lungs. On the other hand, particles larger than $4 \mu \mathrm{m}$ normally deposit in the mouth and throat [22]. Essentially, the heights at which smoke is observed is critical as it determines the lifetime of the pollutants, their downwind transport dispersion pathways and the magnitude of their environmental and health impacts [23,24]. Val Martin et al. [25] further showed that observed altitudes of smoke vary with vegetation type, geographic location and season.

$\mathrm{CO}$ and $\mathrm{BC}$ particles can be observed at the lower parts of the stratosphere and are able to cause strong radiative forcing [26]. An estimate by Wang et al. [27] showed that the global scale BC radiative forcing can reach $+0.53 \mathrm{~W} \mathrm{~m}^{-2}$ (after removing the preindustrial background) indicating a greater contribution to warming influence. As a result, BC is considered a significant climate warming agent [28]. It can increase the absorption of incoming solar radiation (primarily visible wavelengths), it can reduce the surface albedo of snow and ice, thus accelerating melting, and it can alter the number and composition of small particles on which water vapour condenses, thus affecting the lifetime, 
reflectivity and stability of clouds [29]. Therefore, studying the sources of BC, its spatial and vertical height distribution has become the key focus in the recent literature due to devastating climate and health implications [30-32].

Datasets from sensors such as the Cloud-Aerosol Lidar and Infrared Pathfinder Satellite Observation (CALIPSO) and reanalysis data such as the Modern-Era Retrospective analysis for Research and Applications-Version 2 (MERRA-2) have been instrumental in characterising the Spatio-temporal and vertical patterns of smoke, BC and CO. For example, using CALIPSO data, Shikwambana [33] showed that biomass burning is responsible for a substantial amount of smoke aerosols in central Africa during the June-July-August (JJA) season. On the other hand, Lasko et al. [34] used the MERRA-2 reanalysis BC concentration data from 2012-2016 to explore the pollution trends over time. Their results show that forest biomass burning from Northwest Vietnam and Laos impacts on the air quality of Hanoi during the peak Ultraviolet Aerosol Index (UVAI) months of March and April. However, these studies are limited in scope and have a specific focus on one aspect of wildfire impacts, such as air quality, without simultaneously considering the impacts on land surface changes and vice versa. The effects of wildfires are interrelated, i.e., have implications for both the surface and atmospheric changes. Therefore, a comprehensive study that characterises land-atmosphere interactions with regard to wildfires is critical in understanding the spatial distribution, frequency, disturbance characteristics, variability and distribution, of pollutants (such as smoke, BC and CO) from wildfires. This paper addresses this gap using multisource remotely sensed data, reanalysis data and trend analysis over a period of 9 years, i.e., 2007-2016. The objectives of the study are to (1) study the sources of wildfires and the period they are prevalent in sub-Saharan Africa, (2) estimate the seasonal disturbance of wildfires on various vegetation types and (3) determine the spatial distribution of black carbon, carbon monoxide and smoke, and (4) determine the vertical height distribution of smoke.

\section{Study Area}

The study area consists of the Sub-Saharan African (SSA) region covering latitudes of between $25^{\circ} \mathrm{N}$ and $35^{\circ} \mathrm{S}$ (Figure 1). This area is characterised by a number of biomes that are habitats to thousands of terrestrial mammals, birds, herpetofauna and vascular plants. The area around the equator consists of mainly tropical forests, whilst subtropical areas consist of tropical and subtropical Savanna. Most of southern Africa consists of temperate Grasslands, Savanna and Shrubland, as well as Mediterranean forests. Parts of the SSA region also consists of deserts and Xeric Shrublands [35]. A detailed land cover map for 2015 is given in Figure 1. The study area was chosen because it is mostly affected by wildfires resulting from anthropogenic and natural activities and has been found to constitute about $70 \%$ of the total burned area across the world [16]. 


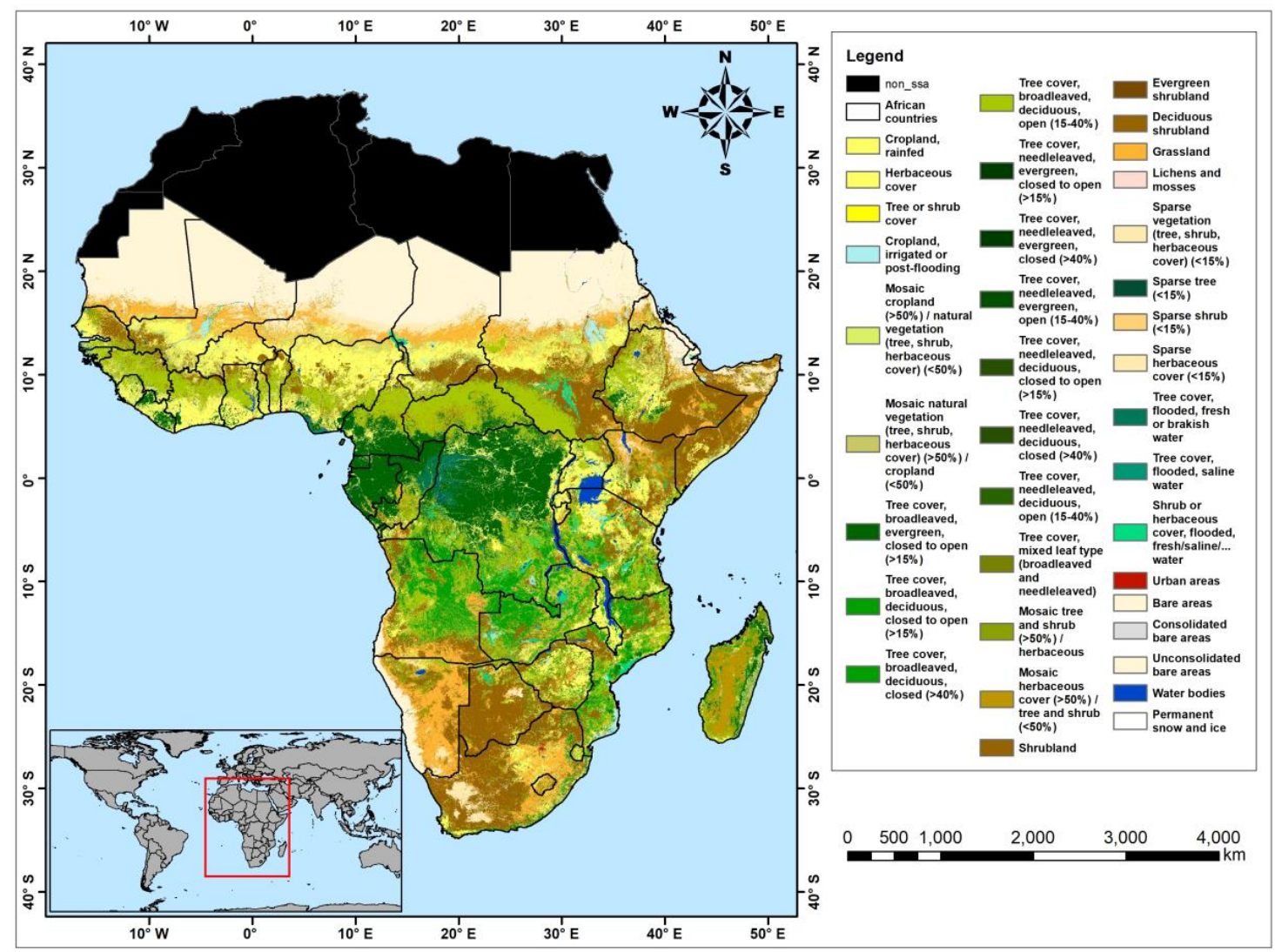

Figure 1. Land Cover map of Africa. The study area consisted of Sub-Saharan Africa (SSA) at $\sim 20^{\circ} \mathrm{N}$ and $\sim 35^{\circ} \mathrm{S}$. The areas in black did not form part of the study.

\section{Materials and Methods}

\subsection{Burned Area}

The Moderate Resolution Imaging Spectroradiometer (MODIS) Burned Area (BA) product (MCD64A1) version 6 contains monthly burned-area and quality information per-pixel on global scales, at a $500 \mathrm{~m}$ spatial resolution. The MCD64A1 was derived using the Collection 6 algorithm that identifies, at the time of satellite overpass, pixels that contain one or more actively burning fires using brightness temperatures [7,36]. Collection 6 BA algorithm is an improvement of Collection 5.1 MCD64A1 and Collection 5.1 MCD45A1 mapping algorithms. The algorithm has reportedly better detection rate for small burns, has reduced temporal uncertainty and extent of unmapped areas that the product detects [11,37]. The annual total burn area (BA) and pixel-wise frequency of fire incidence per season (i.e., DJF, MAM, JJA, SON) were derived by aggregating MCD64A1 Burn Date product in Google Earth Engine (GEE). From our knowledge, no similar study has been found yet that used MCD64A1.v6 to benefit from its improvements.

\subsection{Precipitation}

Tropical Rainfall Measuring Mission (TRMM) dataset is produced based on Algorithm 3B43 that merges several precipitation estimates from multiple microwave orbital sensors and intercalibrated to the TRMM Combined Instrument. The algorithm produces monthly scale precipitation rate (in $\mathrm{mm} / \mathrm{month}$ ) by combining the 3-hourly merged high-quality/IR estimates (3B42) with the monthly surface precipitation accumulated Global Precipitation Climatology Centre (GPCC) rain gauge analysis. The Monthly Precipitation Estimates (TRMM 3B43) dataset has a spatial resolution of $0.25^{\circ} \times 0.25^{\circ}$. 


\subsection{Land Cover}

The land cover data utilised in this study, i.e., ESA Climate Change Initiative Land Cover (CCI-LC) was generated from global daily reflectance measurements from 1992 to 2015 acquired by multiple Earth observation systems, namely, MEdium Resolution Imaging Spectrometer (MERIS, 2003-2012), Advanced Very High Resolution Radiometer (AVHRR, 1992-1999), Satellite Pour l'Observation de la Terre Vegetation (SPOT-VGT, 1999-2013) and PROBA-Vegetation (PROBA-V, 2014-2015). The land cover classification was based on both unsupervised and supervised algorithms, time-series data and a United Nations Land Cover Classification System (UN-LCSS) containing 37 classes that describe Earth's terrestrial surface [38]. The use of multi-temporal, multi-sensor data allowed backwards and forward cross-checking to detect and verify land cover changes and eliminate false changes as a result of inter-annual variability. The CCI-LC database consists of 24 annual land cover maps spanning from 1992 to 2015 at a spatial resolution of 300 m [39,40]. The CCI-LC data from 2007 to 2015 were used in this study to determine burned land cover per season. Detailed Level 2 classes were reclassified to Level 1 classes [38] and non-vegetation classes were removed.

\subsection{Modern-Era Retrospective Analysis for Research and Applications Version 2 (MERRA-2)}

The Modern-Era Retrospective analysis for Research and Applications, Version 2 (MERRA-2) supplies data from 1980 to the present. MERRA-2 was developed to improve and extend the original MERRA dataset [41] which finished in February 2016. MERRA uses 3-dimensional variational data assimilation (3DVAR) analysis algorithm based on the GridPoint Statistical Interpolation (GPS) scheme with a 6-h update cycle. MERRA makes comprehensive use of satellite radiance data from both operational and research instruments, including data from hyperspectral instruments. The assimilation of radiance data need a forward radiative transfer model (RTM) as the observation operator, to calculate the model-equivalent radiances, and the corresponding Jacobian to calculate the influences in model space of the radiance increments calculated from the analysis. The successful implementation of radiance data needs cautious quality control and bias correction procedures that are channel-specific. The bias in a given satellite channel can vary considerably in space and time, depending on the systematic errors in the radiative transfer model, atmospheric conditions and the quality and age of the instrument. In most data assimilation schemes, the bias in each satellite radiance measurement is represented by a linear predictor model with a relatively small number $(\sim 10)$ of parameters. In MERRA-2, aerosol and meteorological observations are jointly assimilated within Goddard Earth Observing System Model, Version 5 (GEOS-5) [42,43]. The system assimilated MODIS, Advanced very high-resolution radiometer (AVHRR), Multi-angle Imaging SpectroRadiometer (MISR) and AErosol RObotic NETwork (AERONET) data. More details on MERRA can be found in Rienecker et al. [41]. The datasets used in this study are the black carbon extinction $550 \mathrm{~nm}$, carbon monoxide concentration and latent heat flux overland products.

\subsection{CALIPSO (Cloud-Aerosol Lidar and Infrared Pathfinder Satellite Observations)}

The CALIPSO satellite was launched on 28 April 2006 and is an integral part of NASA's A-Train satellite constellation [44]. Its main function is to study the role that aerosols and clouds play in regulating the earth's climate, weather and air quality. The main objectives of the CALIPSO are to (1) provide statistics on the vertical structure of clouds around the globe, (2) detect sub-visible clouds in the upper troposphere and Polar Stratospheric Clouds (PSC), and (3) provide statistics on the geographic and vertical distribution of aerosols and clouds around the globe. The primary instrument aboard CALIPSO is the Cloud-Aerosol Lidar with Orthogonal Polarization (CALIOP), a two-wavelength laser (532 nm and $1064 \mathrm{~nm}$ ) operating at a pulse repetition rate of $20.16 \mathrm{~Hz}$ [45]. More information on the technical specifications of CALIPSO can be found in Winker et al. [46] and Winker et al. [47]. Furthermore, Hunt, Winker, Vaughan, Powell, Lucker and Weimer [45] gives a detailed discussion on the algorithm that was developed to identify aerosol and cloud layers and 
to retrieve a variety of optical and microphysical properties. The data used in this study are smoke AOD $532 \mathrm{~nm}$ and smoke extinction coefficients $532 \mathrm{~nm}$.

\subsection{AIRS (Atmospheric Infrared Sounder)}

The Atmospheric Infrared Sounder (AIRS) on the EOS/Aqua satellite was launched in polar orbit in May 2002. AIRS is a high spectral resolution spectrometer with 2378 IR channels between 3.74 and 4.61, 6.20-8.22 and 8.8-15.5 $\mu \mathrm{m}$ [48], which is essential for atmospheric temperature and relative humidity soundings. AIRS also has four visible and near-IR channels between 0.40 and $0.94 \mu \mathrm{m}$, which are mainly used for the detection of clouds in the IR FOV. The AIRS retrieval algorithm has been developed and validated gradually with a clear sky and clear/cloudy conditions over a non-frozen ocean, and then the non-polar land and polar cases [49]. Retrievals yield cloud fraction, cloud top pressure and temperature, surface temperature, and vertical profiles of temperature and water vapour. The measurements' vertical resolution and uncertainties are described by Aumann et al. [48]. In this study, relative humidity data were used.

\subsection{Mann-Kendall Test}

The Mann-Kendall Trend Test (MK test) [50,51] is used to analyse data collected over time for characterising in a consistent manner, increasing or decreasing trends in $\mathrm{Y}$ values. This is a non-parametric rank-based test method which is commonly used to identify monotonic trends in a time series [52] of climate data, environmental data and hydrological data. The MK test is known for its robustness to outliers, because its statistic is based on the sign of differences, rather than actual values of the parameter $(\alpha=0.05)$.

The test is based on the statistic $S$ defined as follows:

$$
S=\sum_{i=1}^{n-1} \sum_{j=i+1}^{n} \operatorname{sign}\left(X_{j}-X_{i}\right)
$$

where $n$ is the number of data points, $x_{j}$ and $x_{i}$ are data values at time $j$ and $i(j>i)$, respectively.

Denoting $x=\left(x_{j}-x_{i}\right)$

$$
\operatorname{sign}(x)\left\{\begin{array}{c}
+1, \text { if } x>1 \\
0, \text { if } x=0 \\
-1, \text { if } x<1
\end{array}\right.
$$

For large samples $(n>10)$, the sampling distribution $S$ is assumed to be normally distributed with zero mean and variance as follows:

$$
\operatorname{Var}(S)=\frac{n(n-1)(2 n+5)-\sum_{i}^{n} t_{i}\left(t_{i}-1\right)\left(2 t_{i}+5\right)}{18}
$$

where $n$ is the number of tied (zero difference between compared values) groups and $t_{i}$ is the number of data points in the $i$ th tied group. The Z-statistic or standard normal deviate is then computed by using the equation:

$$
Z=\left\{\begin{array}{c}
\frac{S-1}{\sqrt{\operatorname{Var}(S)}} \text { if } S>0 \\
0 \text { if } S=0 \\
\frac{S+1}{\sqrt{\operatorname{Var}(S)}} \text { if }<0
\end{array}\right.
$$

If the computed value of $Z>Z_{\frac{\alpha}{2}}$, then the null hypothesis of no trend is rejected at $\alpha$ level of significance in a two-sided test (i.e., the trend is significant). In this study, the null hypothesis was tested at a $5 \%$ significance level. 


\subsection{Sequential Mann-Kendall Test}

The Sequential Mann-Kendall Test (SQMK) proposed by Sneyers [53] is important for determining changes of a trend over time. This test sets up two series, a progressive $u(t)$ and a backward (retrograde) series $u^{\prime}(t)$. If they cross each other and diverge beyond the specific threshold value, then there is a statistically significant trend. The point where they cross each other indicates the approximate year at which the trend begins [54]. Whenever the progressive $(u(t))$ or the retrograde $u^{\prime}(t)$ row exceeds certain limits, before and after the crossing point, the null hypothesis of the sampled time series has no change points and must be rejected. This trend turning point may be significant at a particular significance level (i.e., a $5 \%$ significance level). If the intersection of $u(t)$ and $u^{\prime}(t)$ occur within \pm 1.96 (that corresponds to the bounds at $5 \%$ significance level) of the standardized statistic, a detectable change has occurred at that point along the temporal time series. The change can be detected by Kendall coefficient $\left(t_{i}\right)$ [55] and when a time series shows a significant trend, the period from which the trend is noticeable can be obtained effectively by this test.

\section{Results}

\subsection{Seasonal Effects of Wildfires on Land Surface Dynamics}

The impacts of wildfires on the environment are multifaceted and complex, varying by extent, burning frequency, distribution and types of emissions $[1,4,33]$. Therefore, in order to characterise the ecological impacts of wildfires, this study employed multisource remotely sensed data from MODIS, MERIS, SPOT, and Proba-V. Generally, the results (see Figure 2) indicate that burned area (BA) vary annually and across different seasons. For example, in the period under study, i.e., 2007-2016, the largest BA is observed during the December-January-February (DJF), June-July-August (JJA), and September-October-November (SON) seasons. On the other hand, the lowest BA is observed during the March-April-May (MAM) season. Considering the year-to-year trends, DJF has the highest BA in 2007 and generally shows a decreasing trend with little annual fluctuations. These fluctuations are sustained by the results of burn frequency (see Figure 3) that indicates that the region between $0^{\circ}$ and $20^{\circ} \mathrm{N}$ has the highest burn frequency during DJF (i.e., $>40 \%$ ) relative to the rest of sub-Saharan Africa.

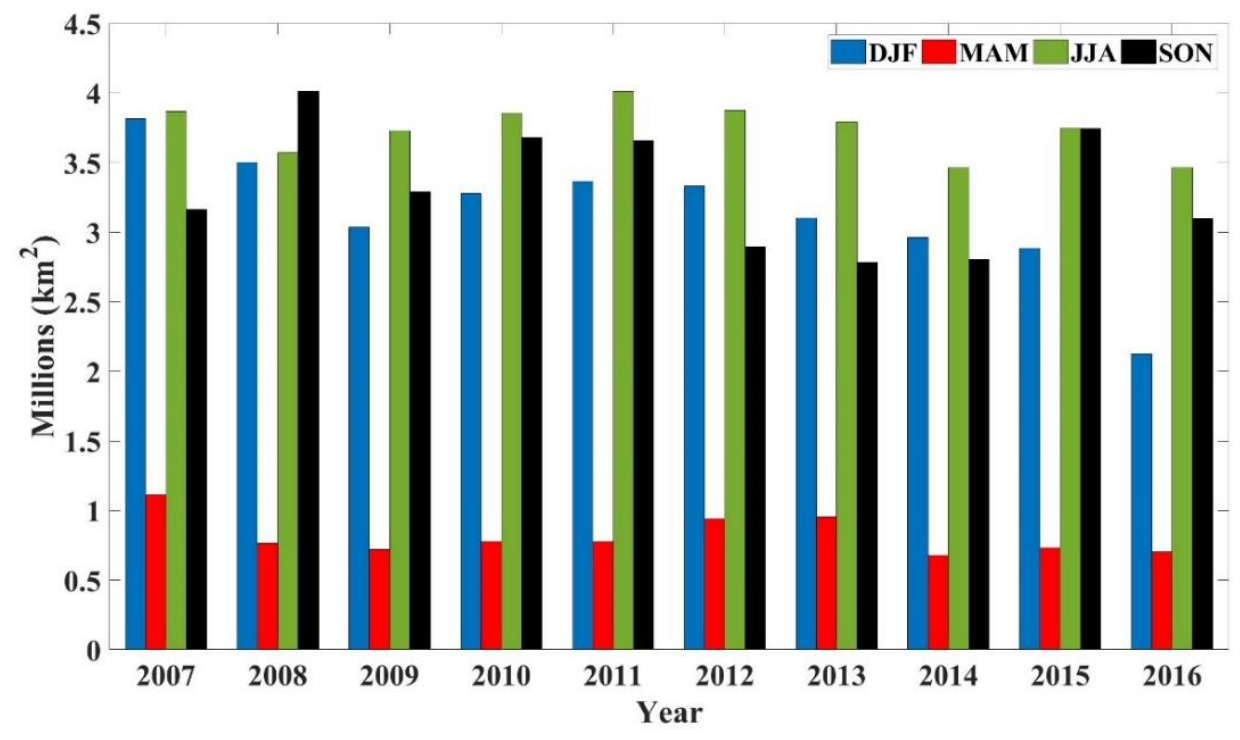

Figure 2. Inter-annual seasonal burned area (BA) over a period of 9 years (i.e., 2007-2016).

On the other hand, the largest BA during the JJA season is observed in 2007 and 2011 while for SON, the largest BA is observed in 2008 and 2015 in the region between $0^{\circ}$ and $25^{\circ} \mathrm{S}$, with moderate to large annual fluctuations. The large BAs in 2007-2008 and 2015 during DJF, JJA and SON seasons can be attributed to drier conditions caused by a strong El Niño climatic event in 2015-2016, and subsequent 
relatively weaker El Niño events in 2006-2007 and 2009-2010, as reported by Verhegghen et al. [56]. In addition, the year-to-year fluctuations observed can be explained by the highest burn frequency (see Figure 3) during these seasons and newly burned areas shown by a lower burn frequency $(<20 \%)$. During SON, only a few areas show a high burn frequency in the region between $0^{\circ}$ and $20^{\circ} \mathrm{N}$. On the other hand, BA during MAM is relatively the lowest across all the years, the highest is recorded in 2007, 2012 and 2013 and generally has a decreasing trend. This is in agreement with the results in Figure 3 that show the lowest burn frequency, i.e., $<20 \%$ distributed between the region $0^{\circ}$ to $25^{\circ} \mathrm{S}$ and $5^{\circ}$ to $15^{\circ} \mathrm{N}$, respectively.

In general, the results of burn frequency and BA imply that most biomass burning in sub-Saharan Africa occur during the DJF season, i.e., mainly in the northern hemisphere. On the other hand, most biomass burning during JJA and SON occurs mainly in the southern hemisphere. The frequently drier conditions as a result of prevailing meteorological conditions, compounded by poor fire management and the susceptibility of certain vegetation types provided suitable conditions for widespread fires during these seasons. For example, warmer and drier conditions increase fuel load and flammability $[57,58]$. The higher burn frequency, i.e., $>40 \%$ during DJF, JJA and SON may have devastating implications for the sustainability of natural forests. This claim is supported by previous studies [59] that show that wildfires may cause tree mortality lasting up to 3 years after the fire, thus, higher burn frequencies provide little time for vegetation recovery. Higher burn frequency ( $>40 \%$ over 9-years period) during DJF at latitudes between $0^{\circ}$ and $\sim 12^{\circ} \mathrm{N}$, and during JJA and SON between latitudes $0^{\circ}$ and $25^{\circ} \mathrm{S}$ may result in permanent loss of habitats for millions of plants, birds and mammal species, forest fragmentation, deforestation, as well as substantial economic losses.

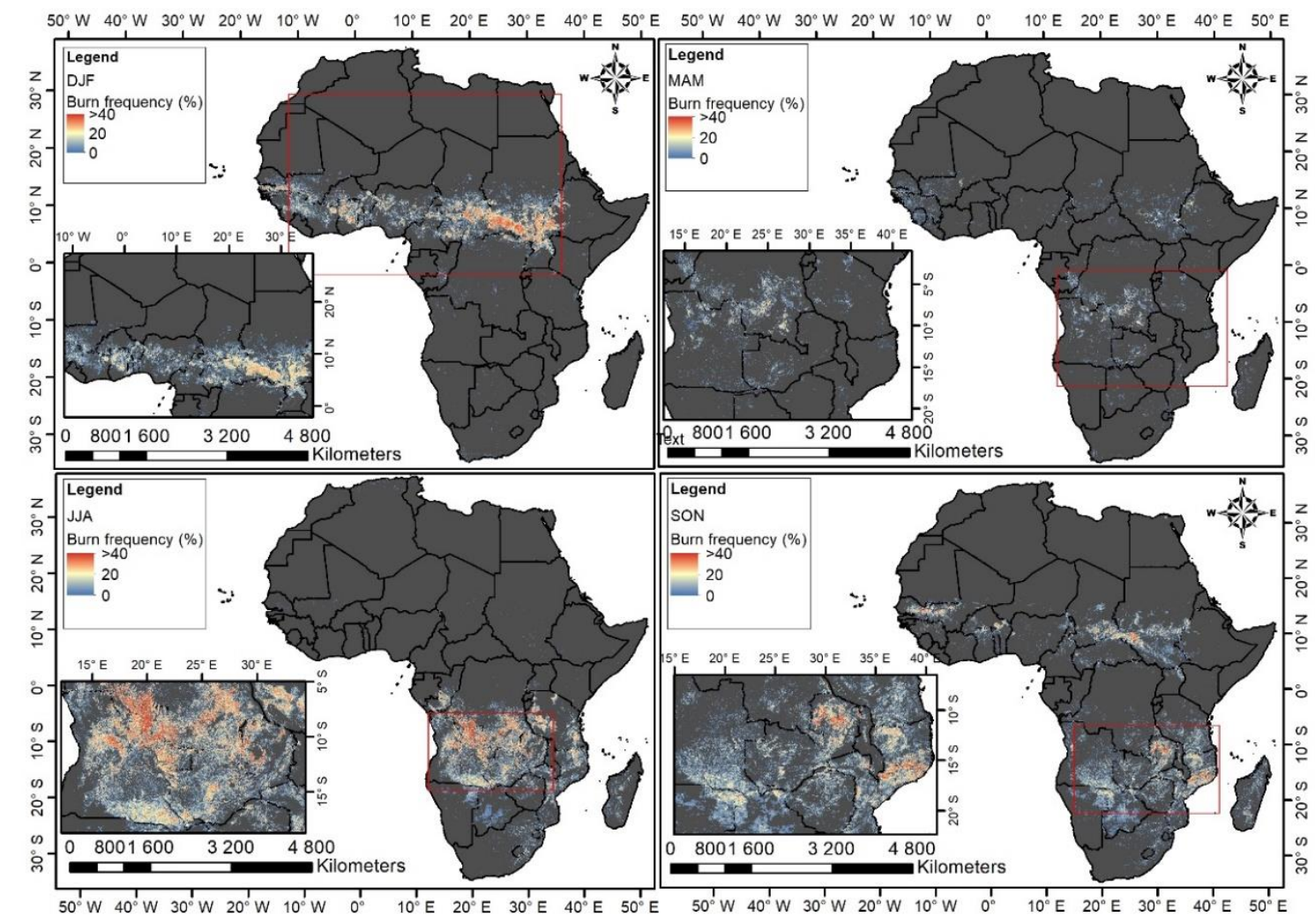

Figure 3. Spatial distribution of Burned areas and Burn frequency (\%) per season over a 9-year period (i.e., 2007-2016).

In order to confirm the vegetation types that were burned on an annual basis per season, we extracted vegetation cover types from the annual CCI-LC data from 2007 to 2015 based on seasonally aggregated BA. As shown in Figure 4, the BA varies by vegetation cover types, year and 
season. The results show that the greatest proportion of BA across the entire period of study and seasons is dominated by the burning of Broadleaved deciduous trees, Shrublands, Rainfed croplands, Grasslands and Mosaic cropland/natural vegetation. This study found that the burning of Broadleaved deciduous trees is the highest in JJA (i.e., total BA of $\sim 1,716,855 \mathrm{~km}^{2}$ ), followed by DJF (i.e., total BA of $\sim 1,394,991 \mathrm{~km}^{2}$ ) and SON (total BA of $\sim 1,124,044 \mathrm{~km}^{2}$ ). On the contrary, the results show that BA for Shrublands is the highest in SON (i.e. total BA of $\sim 843,180 \mathrm{~km}^{2}$ ), followed by DJF (i.e., total BA of $\sim 699,533 \mathrm{~km}^{2}$ ) and JJA (i.e., total BA of $\sim 580,472 \mathrm{~km}^{2}$ ). Burning of woody vegetation covers such as forests and Shrublands is a common traditional land management practice in Africa for satisfying the requirement of land for food production, particularly by smallholder farmers who often do not have equipment and machinery for land clearing [60]. Under favourable conditions (i.e., higher fuel loads supported by low precipitation, humidity, high air temperatures and strong winds), such fires may spread rapidly, extensively destroying other vegetation cover types in their path [56]. The combustion is also sustained by understory herbaceous vegetation cover in both open and closed forest canopies and thin bark characteristic of closed-canopy forest trees [61,62]. This claim is supported by the results in this study that show that predominant burning of land covers such as Mosaic herbaceous cover/tree and shrubs and Mosaic tree and shrub/herbaceous cover across all seasons.
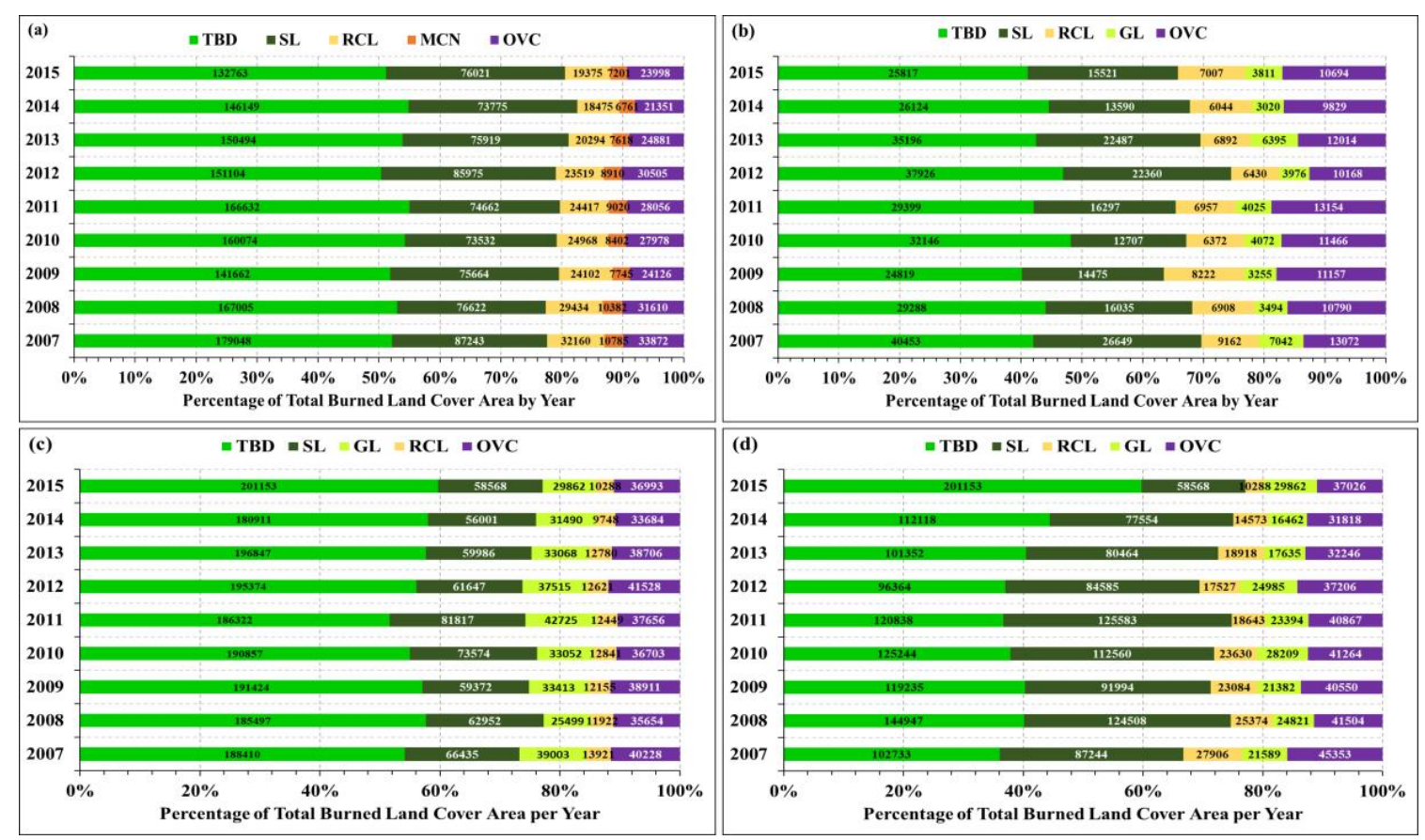

Figure 4. Proportion of burned vegetation cover types by year per season, i.e., (a) DJF, (b) MAM, (c) JJA and (d) SON. TBD = Trees (Broadleaved, deciduous); SL = Shrubland; RCL= Rainfed croplands; $\mathrm{MCN}=$ Mosaic Cropland/Natural vegetation; $\mathrm{GL}=$ Grassland; and OVC $=$ Other vegetation classes, respectively. The numbers on the bars indicate burned areas in $\mathrm{km}^{2}$ per vegetation cover type for each season.

Furthermore, the results show that Grasslands are largely burned during JJA and SON, evidenced by higher BA with a total BA of $\sim 305,757 \mathrm{~km}^{2}$ and $\sim 208,469 \mathrm{~km}^{2}$, respectively. Moreover, Rainfed croplands exhibits higher BA during the DJF and SON with a total BA of $\sim 216,754 \mathrm{~km}^{2}$ and $\sim 179,953 \mathrm{~km}^{2}$, respectively. The burning of Grasslands is often used as a range and pasture management tool [63]. However, the observed higher frequency compounded by prolonged dry conditions during the JJA and SON may result in reduced livestock production due to forage shortages, the proliferation of alien invasive species, bush encroachment, soil erosion and eventually, land degradation [64-66]. Studies by [67] showed that for particular grasslands such as montane grasslands, regular (i.e., annual) burning is beneficial for long-term productivity, while other studies $[66,68,69]$ indicated that the burning 
of semi-arid grasslands may have drastic impacts on grazing capacity, basal cover, productivity and increases the intensity of seasonal droughts. On the other hand, extensive and frequent burning of Rainfed croplands during DJF and SON can be attributed to the burning of post-harvest crop residuals in preparation for the next season [70,71]. The results also suggest that the burning of croplands often extends to other land cover types such as natural vegetation, as shown by predominant burning of Mosaic cropland/natural vegetation and Mosaic natural vegetation/cropland across all seasons. Overall, the results have implications for regional agricultural practices, as well as informing wildfire management and conservation strategies.

MAM (see Figure $4 \mathrm{~b}$ ) exhibits the lowest proportions of burned vegetation cover types compared to other seasons, however, it has similar profiles to other seasons. The least burned vegetation cover types include Broadleaved evergreen forest, Irrigated croplands and Sparse vegetation across all seasons.

\subsection{Seasonal Distribution of $B C, C O$ and Smoke}

In addition to devastating ecological impacts, studies have reported the impacts of wildfires on the chemical composition of the atmosphere, visibility, air quality and climate [15-17]. Contrarily to previous studies [33], this study provides a complementary and detailed analysis of BC, CO and smoke, their sources and variations across seasons. The results (see Figure 5) show an intense plume of $\mathrm{BC}$, smoke and $\mathrm{CO}$ that extends between the $0^{\circ}$ and $18^{\circ} \mathrm{S}$ region over the Atlantic Ocean during JJA season. This is as a result of a large distribution and frequency of wildfires in this region during JJA season, as seen in Figure 3. Vast quantities of agricultural land, forest and grass, in this region, are burned on an annual basis (Figure 4), leading to observed high emissions of BC, smoke and $\mathrm{CO}$. However, other activities are present throughout the year that and contribute to the emissions of $\mathrm{BC}$, smoke and $\mathrm{CO}$ such as domestic fires used for cooking, motor vehicle traffic and industrial activities [72]. The results in Figure 5 further show that JJA is the only season where BC, smoke and $\mathrm{CO}$ have equal dominance in the $0^{\circ}$ to $18^{\circ} \mathrm{S}$ region. On the contrary, smoke is more dominant in the same region than $\mathrm{BC}$ and $\mathrm{CO}$ during SON. This is consistent with the relatively smaller distribution of burned areas during the SON season, as seen in Figure 3. Relatively reduced biomass burning during SON causes reciprocal lower emission of BC and CO. On the other hand, intense plumes of BC and $\mathrm{CO}$, and a less intense plume of smoke are observed during the DJF in the $8^{\circ} \mathrm{N}$ to $12^{\circ} \mathrm{N}$ region. This can be attributed to the main biomass burning activities in this region that include forest and maquis fires, burning of agricultural wastes, and the domestic use of firewood [73]. In agreement, our results, in Figure 4, indicate that the predominantly burning vegetation cover types are Broadleaved deciduous trees, Shrublands and Croplands. It is known that smoke properties vary between fires depending on fuel type and moisture, combustion phase, wind conditions, and several other variables [74]. This might be one of the reasons why lower emissions of smoke are observed during DJF season in the $8^{\circ} \mathrm{N}$ to $12^{\circ} \mathrm{N}$ region. As an example, in Figure 1 , the region between $0^{\circ}$ and $18^{\circ} \mathrm{S}$ consists of mostly sparse trees, needled and broad-leaved trees, whereas the region between $8^{\circ} \mathrm{N}$ and $12^{\circ} \mathrm{N}$ mainly consists of grasslands, mosaic trees and shrubs. It is anticipated that the different fuel types in these regions produce different amounts and properties of smoke, hence the difference in the detection of smoke in these regions [75]. Overall, MAM has the lowest emission of BC, smoke and CO. Lower emissions of $\mathrm{BC}$, smoke and $\mathrm{CO}$ coincides with scattered distribution and relatively smaller burned areas as seen in Figure 3. Other emissions probably come from daily activities such as domestic burning of wood for cooking and motor vehicle emissions. It has been shown that vehicles contribute significantly to the total anthropogenic BC emissions and urban BC concentrations [76]. For example, Efe [77] noted sources such as traffic in highly populated countries such as Nigeria, industry, and oil exploration activities as the major sources of high aerosols in the northern SSA region. However, these emissions sources do not have a strong seasonal pattern at a regional SSA scale. 

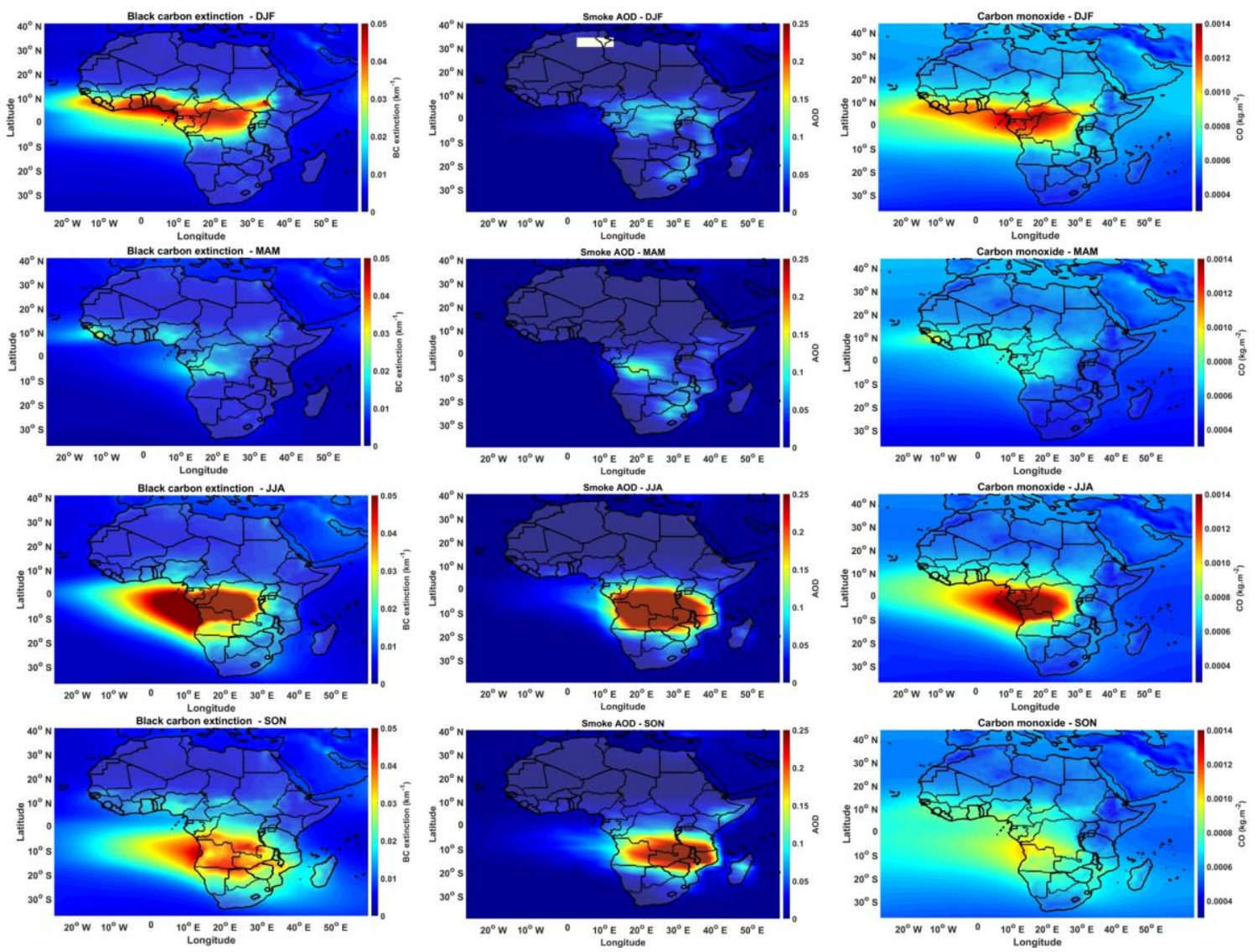

Figure 5. Seasonal sub-Saharan averaged spatial distribution of black carbon extinction and carbon monoxide AOD for 2007-2016 obtained by MERRA-2, and smoke AOD for 2007-2016 obtained by CALIPSO.

Figure 6 shows the seasonal averaged vertical profiles of smoke extinction over the study area for the period 2007-2016. Thick smoke aerosol plumes $(\sim 2 \mathrm{~km})$ are observed for every season at altitudes between 2.4 and $4.5 \mathrm{~km}$. The peaks between 2.4 and $4.5 \mathrm{~km}$ could be due to (1) the development of the planetary boundary layer and (2) transport of smoke aerosols from neighbouring areas contributing to the magnitude of aerosol loading [78]. These results have implications for air quality and subsequently human health and visibility in the SSA region [79]. When smoke aerosols move to higher altitudes, they have a high potential for long-range transport by winds and being transported to downwind areas [80]. Another notable smoke aerosol plume is observed at altitudes between $\sim 5.6$ and $6.3 \mathrm{~km}$ for all seasons except MAM. The source of these smoke plumes is likely attributed to biomass burning. A strong peak at $\sim 3 \mathrm{~km}$ is also observed seasonally. This peak is probably due to the high biomass burning during the drier conditions [81]. At $\sim 3 \mathrm{~km}$, DJF and SON have strong peaks of $\sim 0.24 \mathrm{Mm}^{-1}$ and $0.22 \mathrm{Mm}^{-1}$, respectively, while MAM and JJA have weaker peaks of $\sim 0.18 \mathrm{Mm}^{-1}$ and $0.17 \mathrm{Mm}^{-1}$, respectively. The highest smoke aerosols are detected in DJF season at an altitude of $\sim 10.3 \mathrm{~km}$ with a smoke extinction value of $\sim 0.013 \mathrm{Mm}^{-1}$. Compared to the other seasons, DJF season has the largest detection of smoke at altitudes between 8 and $12 \mathrm{~km}$. On the other hand, JJA has the least detection of smoke between 8 and $12 \mathrm{~km}$. 

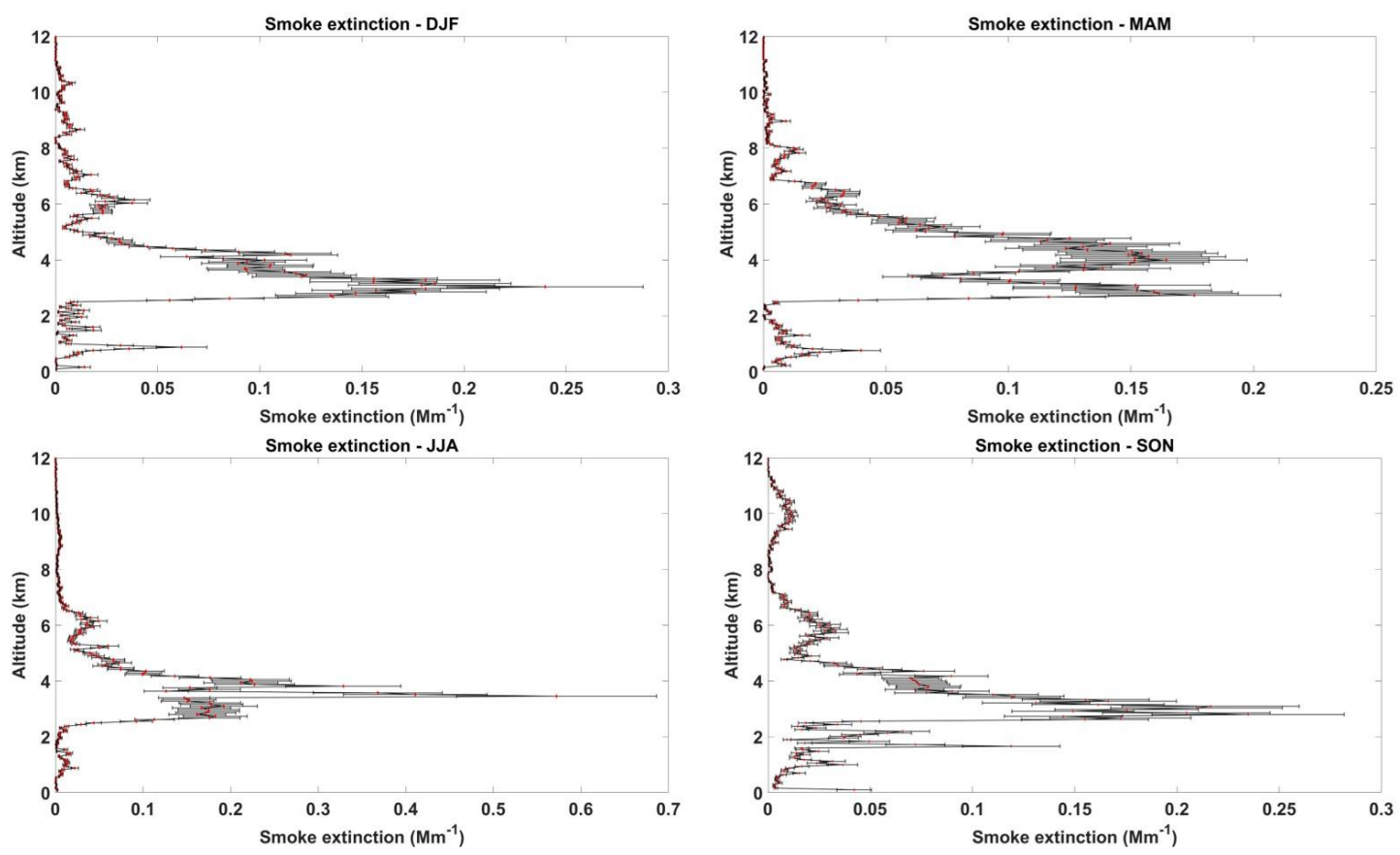

Figure 6. Averaged seasonal vertical height distribution of smoke aerosols over sub-Saharan Africa for the period of 2007-2016. The red dots are the mean values with error bars.

\subsection{The Effect of Meteorological Conditions on the Spatial and Seasonal Changes of Wildfires}

Meteorological conditions such as temperature and humidity show remarkable variability throughout the year, thus, to the patterns of the fire. It is known that the flame over combustible materials is easy to spread at low humidity and difficult at high humidity [82]. In addition, the temperature of the fire will affect the humidity in the air and moisture content within combustible materials [82]. Fires are able to increase surface air temperature predominantly by reducing the latent heat flux due to fire-induced damage to the vegetation [83]. We used precipitation, latent heat flux and relative humidity data to explain the observed seasonal variability of burned area and emissions. The results (see Figure 7) show the seasonal averaged latent heat flux, precipitation and relative humidity over the study area. Latent heat flux is the energy component that best illustrates how vegetation dynamics impact the energy balance of a forest following a fire. The latent heat flux is driven by evaporation of liquid water out of the intercellular spaces within the leaves through the stomata, which are channels from the leaf interior to its surface. When there is no vegetation, the latent heat flux is low, conversely, vegetated surfaces will result in high latent heat flux. Therefore, the recovery of vegetation will result in an increase in latent heat. During the JJA season in the $0-18^{\circ} \mathrm{S}$ region a low latent heat flux $\left(\sim 40 \mathrm{Wm}^{-2}\right)$, a low precipitation $(\sim 50 \mathrm{~mm} / \mathrm{month})$ and low relative humidity $(\sim 40 \%)$ is observed. This is the season with the maximum emissions of BC, smoke and CO (as seen in Figure 4), and widespread BA as well as Burn frequency (as seen in Figure 3). The low latent heat implies an increase in surface air temperature which indicates an increase in the likelihood of intense fires. The intense fire will likely burn more biomass material and inject more $\mathrm{BC}$, smoke and $\mathrm{CO}$ aerosols into the atmosphere. The low precipitation and relative humidity imply drier conditions which favour the spread of wildfires. On the other hand, higher values of latent heat $\left(\sim 140 \mathrm{Wm}^{-2}\right)$, precipitation $(\sim 250 \mathrm{~mm} / \mathrm{month})$ and relative humidity $(60 \%)$ in the $0-18^{\circ} \mathrm{S}$ region are observed in the DJF season. This corresponds to the lowest emissions of BC, smoke and CO (as seen in Figure 4). The wetter conditions in the DJF would make it slightly difficult for the burning of any biomass. Hence, the observed lower BA in this region $\left(0-18^{\circ} \mathrm{S}\right)$. On the other hand, the $8^{\circ} \mathrm{N}$ to $12^{\circ} \mathrm{N}$ region has lower values of latent heat $\left(\sim 80 \mathrm{Wm}^{-2}\right)$, precipitation ( $>\sim 40 \mathrm{~mm} /$ month) and relative humidity $(\sim 30 \%)$ during the DJF season. This is the period with the maximum biomass burning (as seen in Figure 3), mainly of deciduous, broadleaved 
trees, shrubland and rainfed crops (Figure 4), as well as emission of BC, smoke and CO. DJF has the lowest seasonal precipitation in the $8-12^{\circ} \mathrm{N}$ region, implying that this is the driest season. Under warm and dry conditions with low relative humidity, wildfires are easily started. The higher values of latent heat $\left(\sim 140 \mathrm{Wm}^{-2}\right)$, precipitation (up to $\sim 350 \mathrm{~mm} / \mathrm{month}$ ) and relative humidity $(\sim 60 \%)$ are observed in MAM and SON seasons. This corresponds to the low BA and emissions of BC, smoke and $\mathrm{CO}$ in this region. Turco et al. [84] found that the fires activity during the wet conditions is not driven by flammability, rather, it is mainly driven by fuel availability and connectivity. Although the factors that affect wildfires considered in the current study were not exhaustive, the results clearly demonstrate and confirm that meteorological conditions are important in the fire regime, which directly affects the frequency of burning, burned area, and emissions of BC, smoke and CO. Future studies should incorporate various variables in addition to meteorological conditions in order to explain complex relationships between climate, vegetation patterns, wildfires and emissions. Drier conditions result in very intensive fires, rapid spreading of fires and burning of extensive biomass material due to availability of fuel loads [85]. Conversely, wetter conditions result in less intense fires, thus, lower burn area, burn frequency, and lower emissions of $\mathrm{BC}$, smoke and $\mathrm{CO}$.
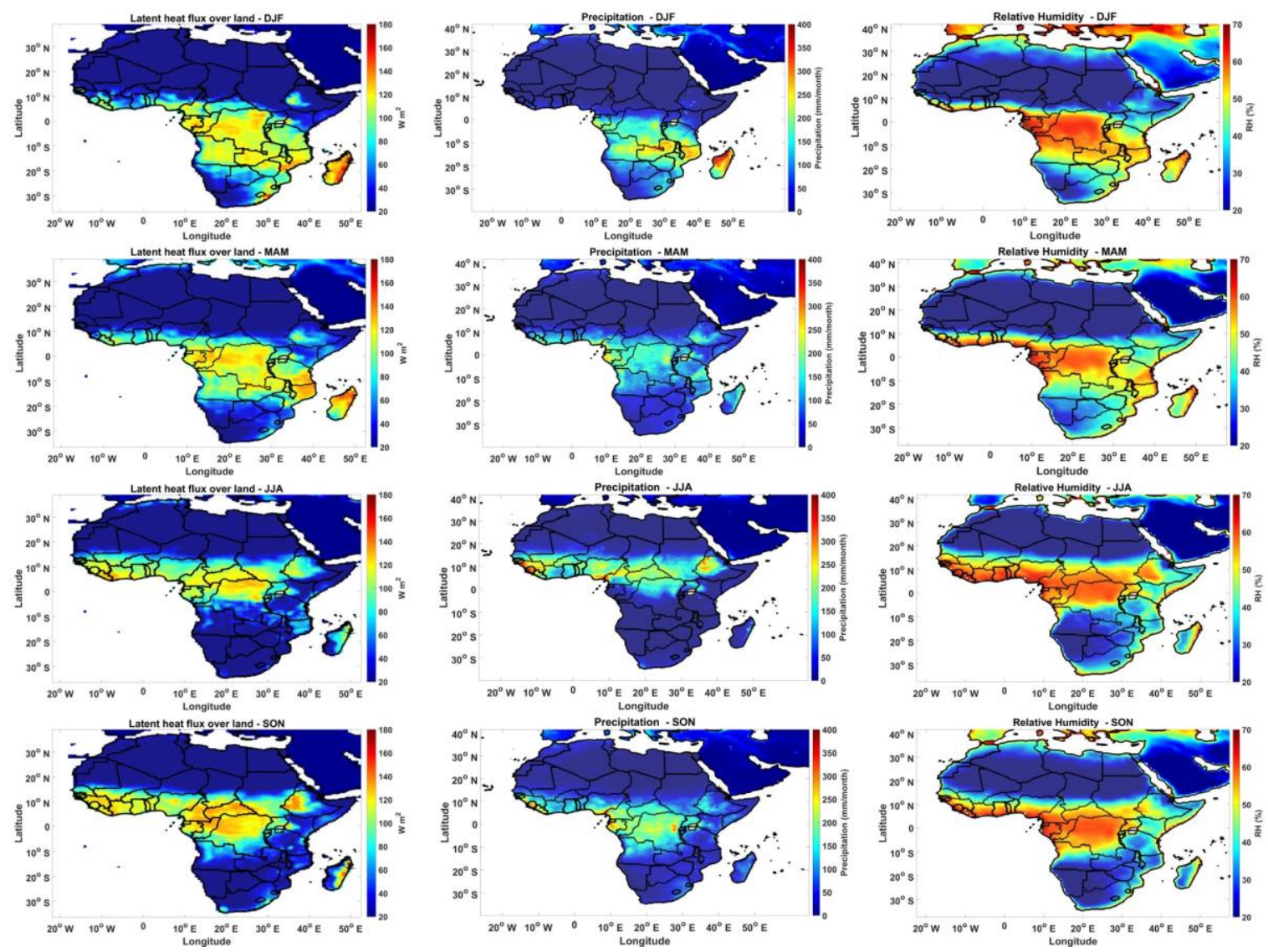

Figure 7. Seasonal sub-Saharan averaged spatial distribution of latent heat flux over land, precipitation and relative humidity for 2007-2016 obtained by MERRA-2, TRMM and AIRS respectively.

\subsection{Seasonal Trend Analysis over the Entire SSA Region}

In order to further understand the temporal variability of wildfires, we employed a linear regression analysis and a Mann-Kendall Trend test in $\mathrm{BC}, \mathrm{CO}$, precipitation, latent heat flux, relative humidity and BA. 


\subsubsection{Linear Regression over the Entire Region}

Linear regression was applied for a trend analysis of BC concentration, $\mathrm{CO}$ concentration, latent heat flux, precipitation, relative humidity and BA in sub-Saharan Africa. The annual time series of these parameters averaged over the whole study period are illustrated in Figure 8. The corresponding interpolated regression lines (in red colour) are also plotted. The variability around a mean value of $\sim 4.5 \times 10^{-10} \mathrm{~kg} \cdot \mathrm{m}^{-3}$ for BC concentration is noticeable, and an increase in the annual average BC concentration is evident, given the slope of the regression line. Marked increases in CO concentration and latent heat flux are also observed from the slope of the regression lines, respectively. The increase in $\mathrm{BC}$ and $\mathrm{CO}$ concentrations are inconsistent with linear regression results for $\mathrm{BA}$, which show no change over time. Therefore, the increase in $\mathrm{BC}$ and $\mathrm{CO}$ could be due to an increase from other emission sources such as biomass cooking stoves, industry, biomass heating stoves, and transport [77]. In fact, the results showing high concentrations of $\mathrm{BC}$, and $\mathrm{CO}$ are consistent with Mehta et al. [86] that found high AOD during the JJA and DJF seasons. The increase in latent heat flux indicates drier conditions leading to a favourable environment for fires. Precipitation, on the other hand, showed inter-annual variability around a mean value of $\sim 80 \mathrm{~mm} / \mathrm{month}$ but exhibits a decreasing trend. The decrease in precipitation implies drier conditions which also favours the spread of fires. Relative humidity shows inter-annual variability around a mean value of $\sim 41 \%$ with a slightly increasing trend. Generally, the lower the relative humidity, the more likely that a fire will start and burn, whereas when humidity is high, evapotranspiration is lower resulting in high moisture preservation by vegetation. Similar to relative humidity, burned area (BA) shows a slightly decreasing trend over time. The decrease can be attributed to the limitation of MODIS BA in detecting fires less than its pixel size, i.e., $500 \mathrm{~m}$.
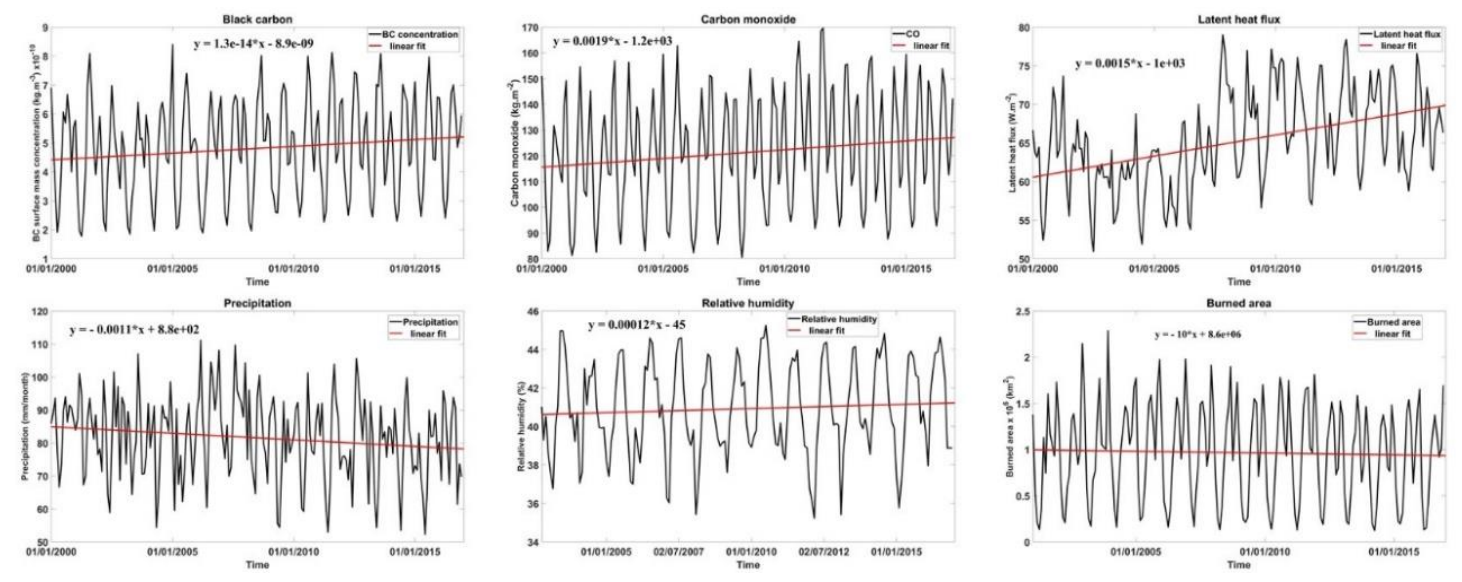

Figure 8. Linear trend analysis of annual black carbon concentration, carbon monoxide concentration, latent heat flux, precipitation, relative humidity and burned area (BA) in sub-Saharan Africa (from 2000 to 2016).

\subsubsection{Mann-Kendall Trend Analysis over the Entire Region}

The MK trend test was run on the annual $\mathrm{BC}, \mathrm{CO}$, latent heat flux, precipitation, relative humidity and BA parameters, to test the null hypothesis $\left(\mathrm{H}_{0}\right)$ that there is no significant trend in the time series at a significance level $\alpha=0.05$. The results are shown in Table 1 . If the $p$-value is less than $\alpha, \mathrm{H}_{0}$ is rejected. Rejecting $\mathrm{H}_{0}$ indicates that there is a trend in the time series, while failure to reject $\mathrm{H}_{0}$ (i.e., $p$-value $>0.05$ ) indicates that no trend was detected. On rejecting the null hypothesis, the time series is said to be statistically significant. The results of the MK test (Table 1) reveal that there is no evidence to support the alternative hypothesis, hence, $\mathrm{H}_{0}$ cannot be rejected ( $p$-value $>0.05$ ) for the time series of $\mathrm{BC}$, relative humidity and burned area. On the other hand, $\mathrm{H}_{0}$ is rejected $(p$-value $<0.05)$ for $\mathrm{CO}$, latent heat flux and precipitation. These trends were further analysed using the sequential MK test. The results are consistent with the linear regression results that indicate an increasing linear trend 
in $\mathrm{CO}$, latent heat flux and precipitation, with the exception of $\mathrm{BC}$, which indicate no significant trend despite increasing linear trend. This may be due to the lower inter-annual variability observed.

The seasonal MK test for the parameters was also investigated and the results are shown in Table 2. For relative humidity, the MK test failed to reject the null hypothesis ( $p$-value $>0.05$ ) for all seasons, which is in agreement with the annual MK test in Table 1. For the latent heat flux, the null hypothesis is rejected $(p$-value $<0.05)$ for all seasons. Unlike relative humidity and latent heat flux, BC shows no significant trend in DJF and SON seasons ( $p$-value $>0.05$ ) while during MAM and JJA seasons, it showed a significant trend ( $p$-value $<0.05)$. The $\mathrm{BC}$ data shows high seasonal variability in term of trends but no significant annual trend (as can be seen in Table 1). The CO data show a significant annual trend $(p$-value $<0.05)$ but no significant seasonal trend except during MAM and JJA seasons. On the other hand, precipitation showed no seasonal significant trend with the exception of DJF season.

Table 1. Results of the Mann-Kendall (MK) test for annual parameters over entire sub-Saharan Africa.

\begin{tabular}{ccc}
\hline Parameter & $p$-Value & $\mathbf{H}_{\mathbf{0}}$ \\
\hline BC & 0.0518 & Failed, No Significant Trend \\
CO & 0.0366 & Rejected, Significant Trend \\
Latent Heat Flux & $1.65 \times 10^{-9}$ & Rejected, Significant Trend \\
Precipitation & 0.0308 & Rejected, Significant Trend \\
Relative Surface Humidity & 0.440 & Failed, No Significant Trend \\
Burn area & 0.754 & Failed, No Significant Trend \\
\hline
\end{tabular}

Table 2. Results of the MK test for seasonal parameters in sub-Saharan Africa.

\begin{tabular}{ccccc}
\hline \multirow{2}{*}{ Parameter } & DJF & MAM & JJA & SON \\
\cline { 2 - 5 } & $p$-Value & $p$-Value & $p$-Value & $p$-Value \\
\hline BC & 0.1096 & $0.0074^{*}$ & $0.0124 *$ & 0.9870 \\
CO & 0.7330 & $0.0028^{*}$ & $1.202 \times 10^{-4 *}$ & 0.9224 \\
Latent Heat Flux & $0.0047^{*}$ & $7.720 \times 10^{-4 *}$ & $1.402 \times 10^{-6 *}$ & $6.09 \times 10^{-4} *$ \\
Precipitation & $0.0230^{*}$ & 0.3379 & 0.3461 & 0.3630 \\
Relative Surface & 0.7220 & 0.1292 & 0.8965 & 0.8679 \\
Humidity & 0.2984 & 0.0831 & $3.798 \times 10^{-9} *$ & $3.906 \times 10^{-4} *$ \\
Burn area & The asterisk (*) indicates that the trend is significant.
\end{tabular}

\subsubsection{Sequential Mann-Kendall Analysis over the Entire Region}

The SQMK test was applied for annual and seasonal parameters to identify how the trend gets fluctuated over the study period. The graphical illustration of the results of the sequential MK test for BC concentration is shown in Figure 9. There was no significant trend detected in BC concentration in the annual data, and the DJF and SON seasons. The multiple turning points on these datasets is one of the reasons for the lack of trend. Another reason for the lack of trend could be what seems to be a convergence of the progressive and retrograde series in 2015. The MAM and JJA seasons show increasing trends of the BC concentration. The relative humidity dataset (see Figure 10) did not show any trend in the annual dataset and for all seasons. The reason that there is no trend for the annual and DJF datasets is that there is no intersection point between the progressive and retrograde series. For the MAM, JJA and SON seasons, there are multiple intersections points between the progressive and retrograde series and these curve do not diverge to show a trend. The latent heat flux dataset (see Figure 11) shows a significant increasing trend for the annual dataset and all the seasons. The increase in latent heat flux implies drier environmental conditions. 

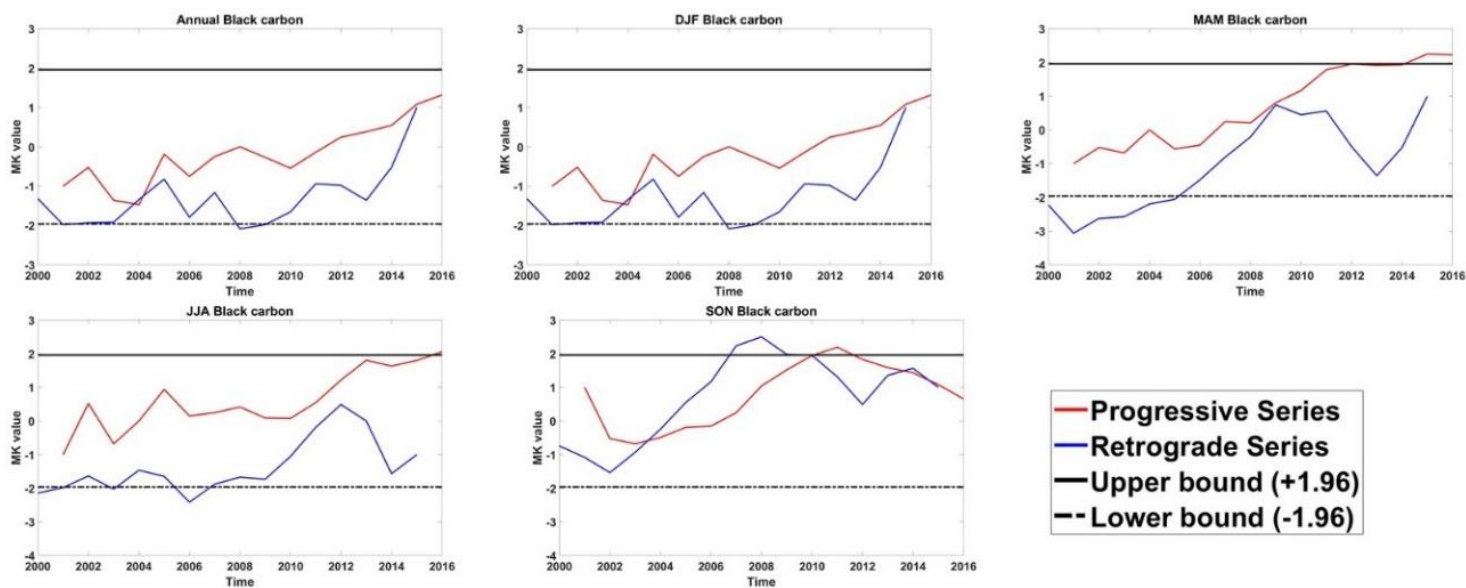

Figure 9. Sequential MK values for annual and seasonal BC concentration series in sub-Saharan Africa.
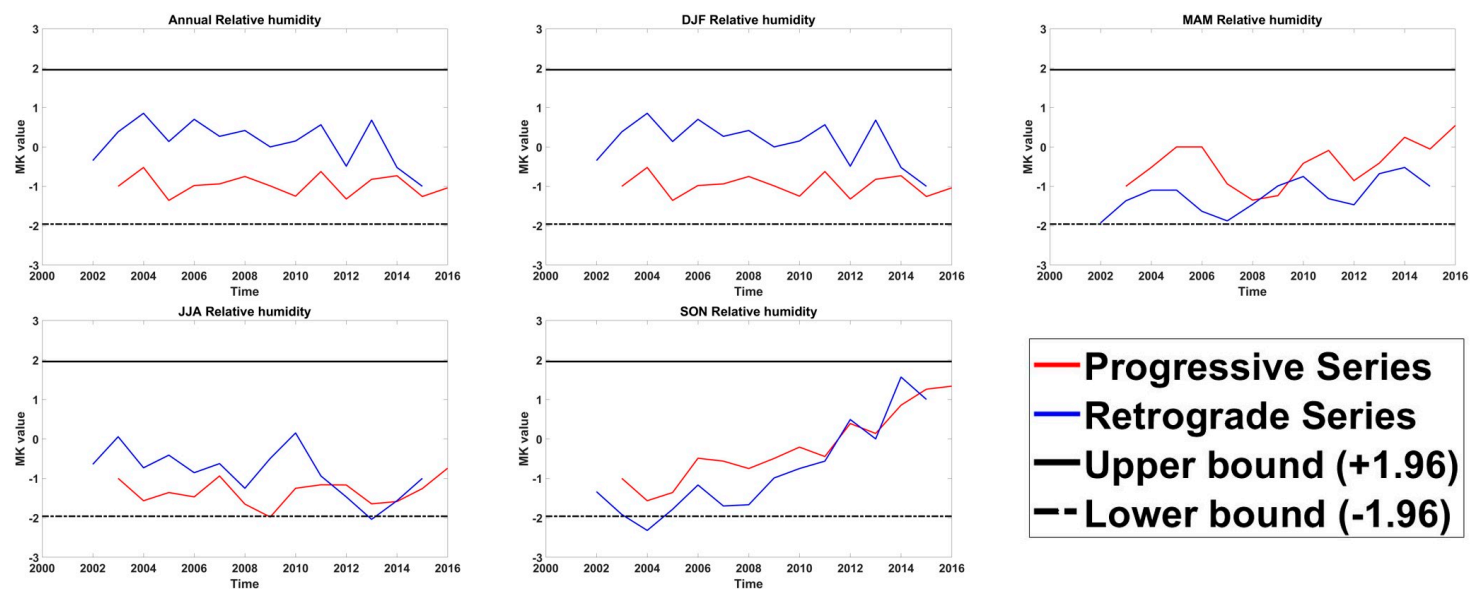

Figure 10. Sequential MK values for annual and seasonal relative humidity series in sub-Saharan Africa.
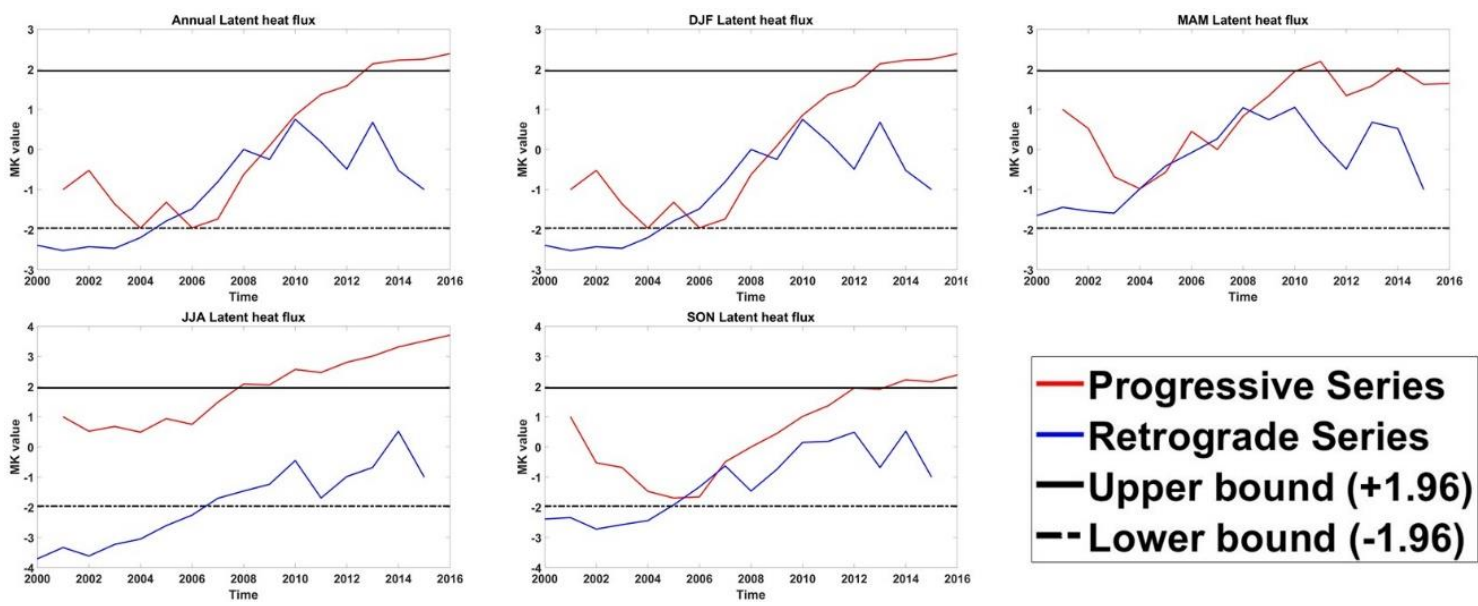

Figure 11. Sequential MK values for annual and seasonal latent heat flux series in sub-Saharan Africa.

\subsection{Seasonal Trend Analysis over Northern and Southern Sub-regions of the SSA}

In order to study, in detail, the sub-regions and seasons where large plumes of $\mathrm{CO}$, smoke and BC were observed, a trend analysis was carried out over northern SSA region $\left(0-11^{\circ} \mathrm{N}\right)$ and the southern SSA region $\left(0-17^{\circ} \mathrm{S}\right)$. This was done to exclude the influence to the trend and patterns that may be coming from areas and seasons where there is limited fire activity when the entire SSA region is analysed. 
The results in Table 3 show the MK test for BC, latent heat flux and relative surface humidity over the northern and southern SSA regions respectively. On the other hand, Figures 12 and 13 show the results of linear regression and SQMK test, performed to determine the direction and magnitude of the trend since this information could not be obtained from MK test alone. Generally, the results during DJF for the northern SSA region are consistent with the results over the entire region (see Tables 1 and 2) that show no significant trend in BC and relative surface humidity.

Table 3. Results of the MK test for BC and meteorological conditions in the northern and southern sub-region where large emission plumes were observed.

\begin{tabular}{ccc}
\hline \multirow{2}{*}{ Parameter } & Northern SSA & Southern SSA \\
\cline { 2 - 3 } & $\boldsymbol{p}$-Value & $\boldsymbol{p}$-Value \\
\hline BC & 0.05 & 0.08 \\
Latent Heat Flux & $6.0797 \times 10^{-6}$ & 0.39 \\
Relative Surface Humidity & 0.51 & 0.80 \\
\hline
\end{tabular}
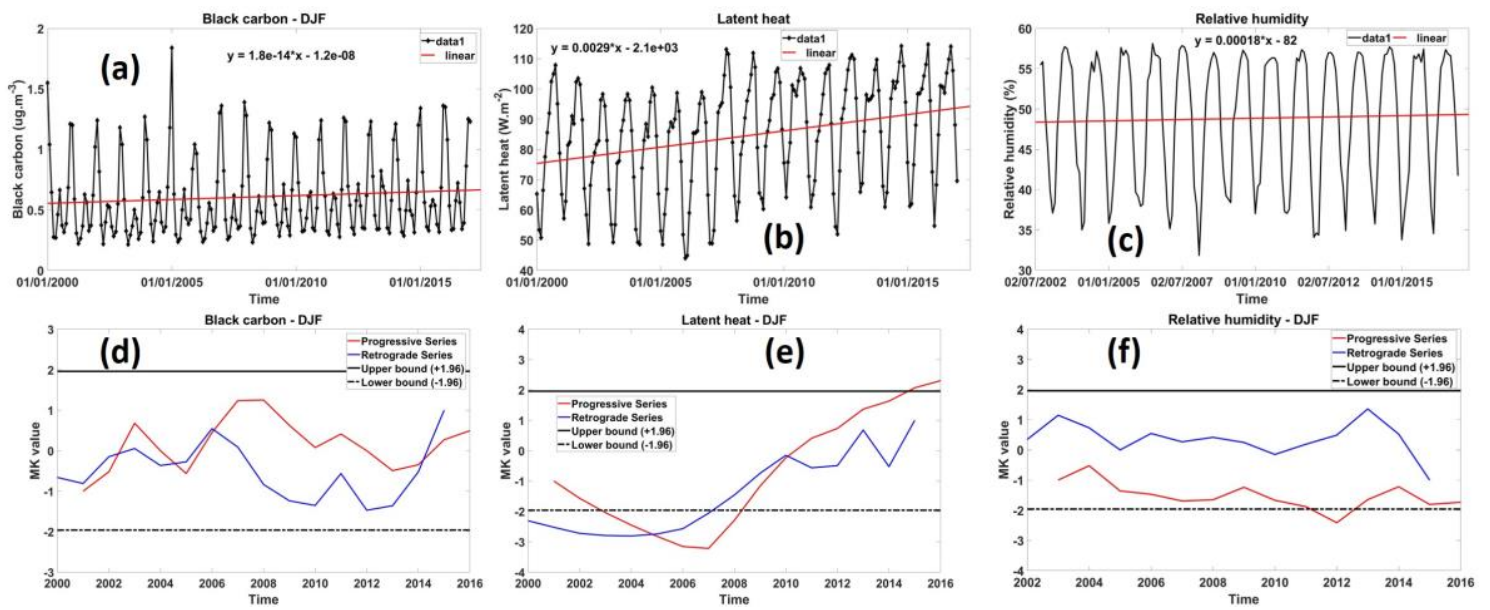

Figure 12. Linear trend analysis for (a) black carbon, (b) latent heat flux and (c) relative humidity for northern SSA $\left(0-11^{\circ} \mathrm{N}\right)$ that showed a large plume of BC and CO during the DJF season. Sequential MK plots for (d) black carbon, (e) latent heat flux and (f) relative humidity during the DJF season.
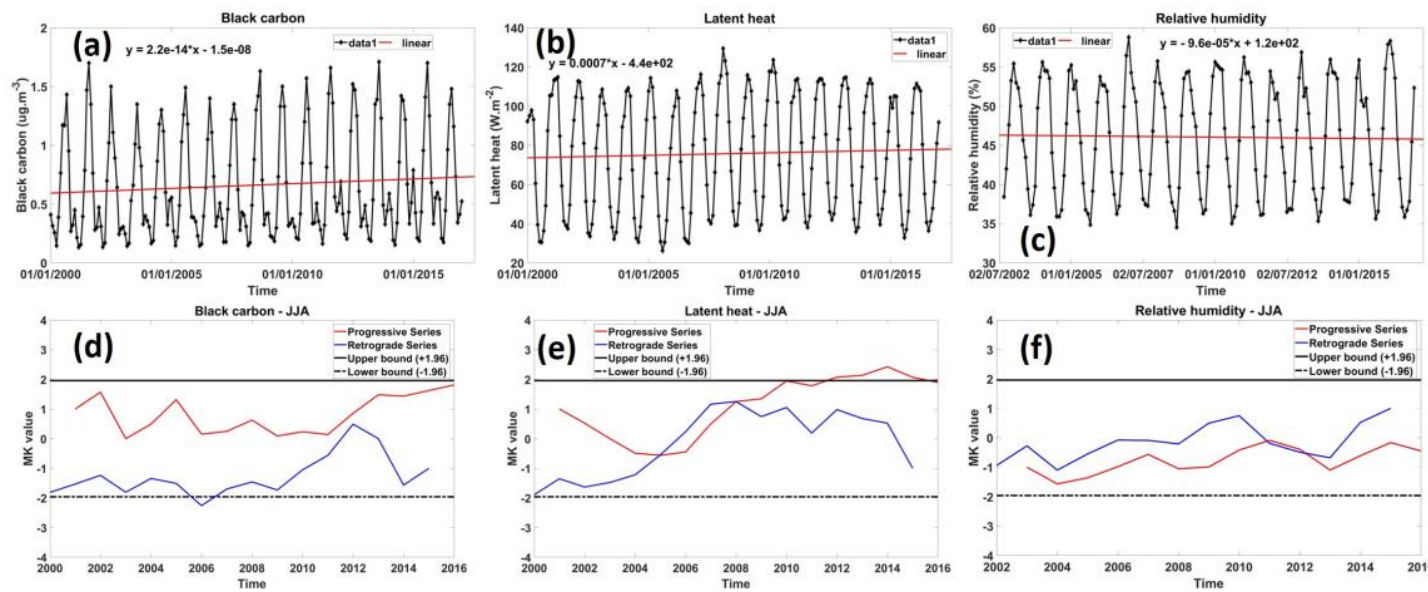

Figure 13. Linear trend analysis for (a) black carbon, (b) latent heat flux and (c) relative humidity for northern SSA $\left(0-17^{\circ} \mathrm{S}\right)$ that showed a large plume of BC and CO during the DJF season. Sequential MK plots for (d) black carbon, (e) latent heat flux and (f) relative humidity during the DJF season.

Similarly, the results of linear regression show a slight increase in BC and relative humidity given the slope of linear regression (Figure 12a-c). This increase in BC in the northern SSA region is 
due to biomass burning from north to south of the Sahel region that occurs in DJF [87]. However, multiple turning points in the SQMK test results indicate that there is no trend. The lack of trend in the northern SSA region can be attributed to the greening of the Sahel region, as reported by various studies [88-90]. The trend analysis of latent heat flux using both linear regression and the SQMK test shows a significantly increasing trend, evidenced by the single turning point in 2006. In general, it is known that the latent heat flux increase is largely due to global warming which is driven by the increase in temperature. An overview by Collins [91] shows an increasing trend in temperature in the DJF season for the period 2001-2010 in the SSA region. Furthermore, Serdeczny et al. [92] used the high-emission scenario (RCP8.5) and low-emission scenario (RCP2.6) models to show the increasing trend of temperature in the SSA over time. This steady increase of temperature overtime is one factor responsible for the increase in the latent heat flux. Another factor that could contribute to the increase in latent heat flux is the increase in carbon dioxide $\left(\mathrm{CO}_{2}\right)$. It is also known that $\mathrm{CO}_{2}$ is an important gas responsible for regulating the Earth's temperature, where considerable amounts of $\mathrm{CO}_{2}$ result in an increase in temperatures. Contrarily to the global $\mathrm{CO}_{2}$ emission change over the period of 1751 to 2017 observed by Ritchie and Roser [93], this study shows an increase of $\mathrm{CO}_{2}$ emission (1.08 million ton) starting from 2006 over the SSA region for the period 2000 to 2016. This coincides with the period when the increasing trend of latent heat flux is observed. Therefore, the observed increase in $\mathrm{CO}_{2}$ emission have devastating implications for global warming and wildfire frequency, and has caused increase in latent heat flux. Lastly, the El Niño climatic events that occurred in 2006-2007, 2009-2010 and 2015-2016 contributed to a significantly increasing trend in latent heat [56]. This is in agreement with an annual and seasonal analysis over the entire SSA region that shows no significant trend (Figures 8-11).

On the other hand, MK test results over the southern SSA region are different from the result over the entire region. In particular, the results over the southern SSA region show no significant trend in BC, latent heat flux and relative humidity (Table 3), as opposed to SSA wide results that indicate significant trends for $\mathrm{BC}$ and latent heat flux. Moreover, the results of the trend analysis using linear regression and the SQMK test (Figure 13a-c) over the southern SSA region show an increasing trend in BC and latent heat flux, attributable to vast burning activities during the dry season (i.e., JJA) [94]. However, SQMK shows that the observed trend is not significant, attributed to better implementations of environmental policies in this sub-region [86]. On the other hand, the linear regression for relative humidity showed a decreasing trend over time (see Figure 13c). But the SQMK test showed no trend for this parameter (see Figure 13f). These results are consistent with results over the entire region (Figures 8-11).

Overall, the results are relevant for addressing long-term wildfire information scarcity in Africa, developing fire and emissions inventories for SSA and informing regional and national policies in line with the Sustainable Development Goals (SDGs) and other international mandates to reduce and control emissions.

\section{Conclusions}

Although wildfires are crucial for promoting diversity and natural vegetation regeneration [95], their frequency and severity may be devastating for particular vegetation types, causing land degradation, loss of habitats, deforestation and supporting the proliferation of alien invasive plant species. At the same time, wildfires increase the global atmospheric load of trace gases and aerosols, thus affecting air quality, visibility and Earth's radiation balance. This study sought to analyse the surface-atmospheric effects of wildfires in sub-Saharan Africa using multisource remotely sensed, reanalysis data and a trend analysis. The results of this study are in agreement with previous studies [33,96-98], however, this study provided a more comprehensive analysis of simultaneous effects of wildfires on the land surface and atmosphere than most previous studies. For example, a study by Jeong and Wang [96] only considered BC seasonal variations at a global scale, whilst [97] showed seasonality and distributions of active fires at a global scale. Additionally, multisource remotely 
sensed data used in this study were essential in explaining observed long-term and seasonal patterns of wildfires and associated emissions.

Firstly, the results show that frequent wildfires, especially during prolonged dry conditions such as during El Niño events, may result in the disturbance of forest and savannah ecosystems. Additionally, Croplands and Grasslands were amongst the largest burned vegetation cover types after Broadleaved deciduous trees and Shrublands, attributed to agricultural land management practices such as "slash and burn" and pasture management. An analysis of a 9-year period shows that the highest burn frequency, i.e., $>40 \%$ in the regions $0-20^{\circ} \mathrm{N}$ and $0-25^{\circ} \mathrm{S}$, thus indicates a threat to the sustainability of natural forests and rangelands in Africa. However, the burned area might have been underestimated due to the limitations of MODIS spatial resolution in detecting small fires. Future studies should consider fusing various datasets such as MODIS, Landsat and Sentinel-2 to benefit from the improved spatial and temporal resolutions.

Secondly, large emissions and distributions of smoke, $\mathrm{BC}$ and $\mathrm{CO}$ in the $0-18^{\circ} \mathrm{S}$ region are observed during the JJA season as a result of agricultural land, forest and grass burning. Drier conditions influenced by the low latent heat flux, low precipitation and low relative humidity aid in the intensity of the fire. Conversely large emissions and distributions of smoke, $\mathrm{BC}$ and $\mathrm{CO}$ are observed in the $8-12^{\circ} \mathrm{N}$ region during the DJF season. This is consistent with Jeong and Wang [96]. The MAM season shows the least loading of smoke, $\mathrm{BC}$ and $\mathrm{CO}$ both in the $0-18^{\circ} \mathrm{S}$ and $8-12^{\circ} \mathrm{N}$ regions. This is the season that corresponds to the least burned vegetation cover types. This season also comprises of moderate latent heat flux $\left(\sim 20 \mathrm{Wm}^{-2}\right)$, moderate relative humidity $(\sim 60 \%)$ and low precipitation $(\sim 200 \mathrm{~mm} / \mathrm{month})$ which are ideal conditions for intensive fires to occur.

The long-term trend analysis showed linear increasing trends in $\mathrm{BC}, \mathrm{CO}$, latent heat flux and relative humidity datasets. However, in the northern SSA region, MK and SQMK (95\% confidence interval) revealed no significant increasing trend in $\mathrm{BC}$ attributed to the greening of the Sahel region studies [88-90]. Similarly, there was no significant trend in the southern SSA region attributed to better implementations of environmental policies [86].

Overall, the results in this study necessitate better regional fire management and air quality control strategies and enforcement to combat the devastating effects of wildfires, especially during DJF, JJA and SON, to preserve endangered species and habitats, promote sustainable land management, and reduce greenhouse gases (GHG) emissions.

Author Contributions: Conceptualization, L.S. and M.K.; Methodology, L.S. and M.K.; Formal Analysis, L.S. and M.K.; Investigation, L.S. and M.K.; Data Curation, L.S. and M.K.; Writing-Original Draft Preparation, L.S. and M.K.; Writing-Review \& editing, L.S. and M.K.; Visualization, L.S. and M.K.

Funding: This research received no external funding. The APC was funded by South African National Space Agency (SANSA).

Acknowledgments: The authors would like to thank the South African National Space Agency (SANSA) for providing resources for the completion of the study. We acknowledge the GES-DISC Interactive Online Visualization and Analysis Infrastructure (Giovanni) for providing the MERRA-2 data. We thank the NASA Langley Research Centre Atmospheric Science Data Centre for the CALIPSO data. We would also like to thank the anonymous reviewers and the editor who took time to provide useful insights and constructive criticism towards the final crafting of this manuscript.

Conflicts of Interest: The authors declare no conflict of interest.

\section{References}

1. Pio, C.; Legrand, M.; Alves, C.; Oliveira, T.S.; Afonso, J.; Caseiro, A.; Puxbaum, H.; Sanchez-Ochoa, A.; Gelencsér, A.; Pio, C.; et al. Chemical composition of atmospheric aerosols during the 2003 summer intense forest fire period. Atmos. Environ. 2008, 42, 7530-7543. [CrossRef]

2. Chubarova, N.; Nezval, Y.; Sviridenkov, I.; Smirnov, A.; Slutsker, I. Smoke aerosol and its radiative effects during extreme fire event over Central Russia in summer 2010. Atmos. Meas. Tech. 2012, 5, 557-568. [CrossRef] 
3. Forkel, M.; Andela, N.; Harrison, S.P.; Lasslop, G.; Van Marle, M.; Chuvieco, E.; Dorigo, W.; Forrest, M.; Hantson, S.; Heil, A.; et al. Emergent relationships with respect to burned area in global satellite observations and fire-enabled vegetation models. Biogeosciences 2019, 16, 57-76. [CrossRef]

4. Belward, A. The Global Observing System for Climate: Implementation Needs; World Meteorological Organization: Geneva, Switzerland, 2016; p. 315.

5. Hitchcock, H.; Hoffer, R. Mapping a Recent Forest Fire with ERTS-1 MSS Data; NASA: Washington, DC, USA, 1974.

6. Bastarrika, A.; Alvarado, M.; Artano, K.; Martínez, M.P.; Mesanza, A.; Torre, L.; Ramo, R.; Chuvieco, E. BAMS: A tool for supervised burned area mapping using Landsat data. Remote Sens. 2014, 6, 12360-12380. [CrossRef]

7. Giglio, L.; Schroeder, W.; Justice, C.O. The collection 6 MODIS active fire detection algorithm and fire products. Remote. Sens. Environ. 2016, 178, 31-41. [CrossRef] [PubMed]

8. Guindos-Rojas, F.; Arbelo, M.; García-Lázaro, J.R.; Moreno-Ruiz, J.A.; Hernandez-Leal, P.A. Evaluation of a Bayesian Algorithm to Detect Burned Areas in the Canary Islands' Dry Woodlands and Forests Ecoregion Using MODIS Data. Remote Sens. 2018, 10, 789. [CrossRef]

9. Long, T.; Zhang, Z.; He, G.; Jiao, W.; Tang, C.; Wu, B.; Zhang, X.; Wang, G.; Yin, R. 30 m Resolution Global Annual Burned Area Mapping Based on Landsat Images and Google Earth Engine. Remote. Sens. 2019, 11, 489. [CrossRef]

10. Filipponi, F. Exploitation of Sentinel-2 Time Series to Map Burned Areas at the National Level: A Case Study on the 2017 Italy Wildfires. Remote. Sens. 2019, 11, 622. [CrossRef]

11. Humber, M.L.; Boschetti, L.; Giglio, L.; Justice, C.O. Spatial and temporal intercomparison of four global burned area products. Int. J. Digit. Earth 2019, 12, 460-484. [CrossRef]

12. Cardozo, F.d.S.; Shimabukuro, Y.E.; Pereira, G.; Silva, F.B. Using remote sensing products for environmental analysis in South America. Remote Sens. 2011, 3, 2110-2127. [CrossRef]

13. De Sales, F.; Xue, Y.; Okin, G.S. Impact of burned areas on the northern African seasonal climate from the perspective of regional modeling. Clim. Dyn. 2016, 47, 3393-3413. [CrossRef]

14. De Sales, F.; Okin, G.S.; Xue, Y.; Dintwe, K. On the effects of wildfires on precipitation in Southern Africa. Clim. Dyn. 2019, 52, 951-967. [CrossRef]

15. Randerson, J.T.; Chen, Y.; Van Der Werf, G.R.; Rogers, B.M.; Morton, D.C. Global burned area and biomass burning emissions from small fires. J. Geophys. Res. Biogeosci. 2012, 117. [CrossRef]

16. Giglio, L.; Randerson, J.T.; Van Der Werf, G.R. Analysis of daily, monthly, and annual burned area using the fourth-generation global fire emissions database (GFED4). J. Geophys. Res. Biogeosci. 2013, 118, 317-328. [CrossRef]

17. Zielinski, T.; Petelski, T.; Strzalkowska, A.; Pakszys, P.; Makuch, P. Impact of wild forest fires in Eastern Europe on aerosol composition and particle optical properties. Oceanologia 2016, 58, 13-24. [CrossRef]

18. Ito, A.; Penner, J.E. Historical emissions of carbonaceous aerosols from biomass and fossil fuel burning for the period 1870-2000. Glob. Biogeochem. Cycles 2005, 19. [CrossRef]

19. Langmann, B.; Duncan, B.; Textor, C.; Trentmann, J.; van der Werf, G.R. Vegetation fire emissions and their impact on air pollution and climate. Atmos. Environ. 2009, 43, 107-116. [CrossRef]

20. Andreae, M.; Rosenfeld, D.; Artaxo, P.; Costa, A.A.; Frank, G.P.; Longo, K.M.; Silva-Dias, M.A.F. Smoking rain clouds over the Amazon. Science 2004, 303, 1337-1342. [CrossRef]

21. Johnston, F.H.; Henderson, S.B.; Chen, Y.; Randerson, J.T.; Marlier, M.; DeFries, R.S.; Kinney, P.; Bowman, D.M.; Brauer, M. Estimated global mortality attributable to smoke from landscape fires. Environ. Health Perspect. 2012, 120, 695-701. [CrossRef]

22. Shrestha, G.; Traina, S.J.; Swanston, C.W. Black Carbon's Properties and Role in the Environment: A Comprehensive Review. Sustainability 2010, 2, 294-320. [CrossRef]

23. Jian, Y.; Fu, T.-M. Injection heights of springtime biomass-burning plumes over peninsular Southeast Asia and their impacts on long-range pollutant transport. Atmos. Chem. Phys. 2014, 14, 3977-3989. [CrossRef]

24. Zhu, L.; Val Martin, M.; Hecobian, A.; Gatti, L.; Kahn, R.; Fischer, E. Development and implementation of a new biomass burning emissions injection height scheme for the GEOS-Chem model. Geosci. Model Dev. 2018, 2018, 1-30.

25. Martin, M.V.; Kahn, R.A.; Tosca, M.G. A Global Analysis of Wildfire Smoke Injection Heights Derived from Space-Based Multi-Angle Imaging. Remote Sens. 2018, 10, 1609. [CrossRef] 
26. Ditas, J.; Ma, N.; Zhang, Y.; Assmann, D.; Neumaier, M.; Riede, H.; Karu, E.; Williams, J.; Scharffe, D.; Wang, Q.; et al. Strong impact of wildfires on the abundance and aging of black carbon in the lowermost stratosphere. Proc. Natl. Acad. Sci. USA 2018, 115, E11595-E11603. [CrossRef] [PubMed]

27. Wang, W.; Liang, S.; Meyers, T. Validating MODIS land surface temperature products using long-term nighttime ground measurements. Remote Sens. Environ. 2008, 112, 623-635. [CrossRef]

28. Bond, T.C.; Doherty, S.J.; Fahey, D.W.; Forster, P.M.; Berntsen, T.; DeAngelo, B.J.; Flanner, M.G.; Ghan, S.; Kärcher, B.; Koch, D.; et al. Bounding the role of black carbon in the climate system: A scientific assessment. J. Geophys. Res. Atmos. 2013, 118, 5380-5552. [CrossRef]

29. Sims, R.; Gorsevski, V.; Anenberg, S. Black Carbon Mitigation and the Role of the Global Environment Facility: A STAP Advisory Document; United Nations Environment Programme: Nairobi, Kenya, 2015.

30. Woodcock, J.; Edwards, P.; Tonne, C.; Armstrong, B.G.; Ashiru, O.; Banister, D.; Beevers, S.; Chalabi, Z.; Chowdhury, Z.; Cohen, A.; et al. Public health benefits of strategies to reduce greenhouse-gas emissions: Urban land transport. Lancet 2009, 374, 1930-1943. [CrossRef]

31. Ruiz-Mercado, I.; Masera, O.; Zamora, H.; Smith, K.R. Adoption and sustained use of improved cookstoves. Energy Policy 2011, 39, 7557-7566. [CrossRef]

32. Shikwambana, L.; Sivakumar, V. Global distribution of aerosol optical depth in 2015 using CALIPSO level 3 data. J. Atmos. Sol. Terr. Phys. 2018, 173, 150-159. [CrossRef]

33. Shikwambana, L. Long-term observation of global black carbon, organic carbon and smoke using CALIPSO and MERRA-2 data. Remote Sens. Lett. 2019, 10, 373-380. [CrossRef]

34. Lasko, K.; Vadrevu, K.P.; Nguyen, T.T.N. Analysis of air pollution over Hanoi, Vietnam using multi-satellite and MERRA reanalysis datasets. PLoS ONE 2018, 13, e0196629. [CrossRef] [PubMed]

35. Olson, D.M.; Dinerstein, E.; Wikramanayake, E.D.; Burgess, N.D.; Powell, G.V.; Underwood, E.C.; D'amico, J.A.; Itoua, I.; Strand, H.E.; Morrison, J.C. Terrestrial Ecoregions of the World: A New Map of Life on EarthA new global map of terrestrial ecoregions provides an innovative tool for conserving biodiversity. BioScience 2001, 51, 933-938. [CrossRef]

36. Giglio, L.; Justice, C.; Boschetti, L.; Roy, D. MCD64A1 MODIS/Terra+ Aqua Burned Area Monthly L3 Global 500 m SIN Grid V006 [Data Set]; NASA EOSDIS Land Processes DAAC: Sioux Falls, SD, USA, 2015.

37. Giglio, L.; Boschetti, L.; Roy, D.P.; Humber, M.L.; Justice, C.O. The Collection 6 MODIS burned area mapping algorithm and product. Remote Sens. Environ. 2018, 217, 72-85. [CrossRef] [PubMed]

38. Defourny, P.; Brockmann, C.; Bontemps, S.; Lamarche, C.; Santoro, M.; Boettcher, M.; Wevers, J. CCI-LC PUGv2 Phase II. Land Cover Climate Change Initiative-Product User Guide v2. 2017. Available online: https: //www.esa-landcover-cci.org/?q=webfm_send/84 (accessed on 4 August 2019).

39. Li, W.; MacBean, N.; Ciais, P.; Defourny, P.; Lamarche, C.; Bontemps, S.; Houghton, R.A.; Peng, S. Gross and net land cover changes in the main plant functional types derived from the annual ESA CCI land cover maps (1992-2015). Earth Syst. Sci. Data 2018, 10, 219-234. [CrossRef]

40. Bontemps, S.; Defourny, P.; Radoux, J.; Van Bogaert, E.; Lamarche, C.; Achard, F.; Mayaux, P.; Boettcher, M.; Brockmann, C.; Kirches, G. Consistent global land cover maps for climate modelling communities: Current achievements of the ESA's land cover CCI. In Proceedings of the ESA Living Planet Symposium, Edimburgh, UK, 9-13 September 2013; pp. 9-13.

41. Rienecker, M.M.; Suarez, M.J.; Gelaro, R.; Todling, R.; Bacmeister, J.; Liu, E.; Bosilovich, M.G.; Schubert, S.D.; Takacs, L.; Kim, G.-K.; et al. MERRA: NASA's modern-era retrospective analysis for research and applications. J. Clim. 2011, 24, 3624-3648. [CrossRef]

42. Buchard, V.; Da Silva, A.M.; Colarco, P.R.; Darmenov, A.; Randles, C.A.; Govindaraju, R.; Torres, O.; Campbell, J.; Spurr, R. Using the OMI aerosol index and absorption aerosol optical depth to evaluate the NASA MERRA Aerosol Reanalysis. Atmos. Chem. Phys. 2015, 15, 5743. [CrossRef]

43. Buchard, V.; da Silva, A.; Randles, C.; Colarco, P.; Ferrare, R.; Hair, J.; Hostetler, C.; Tackett, J.; Winker, D. Evaluation of the surface $\mathrm{PM}_{2.5}$ in Version 1 of the NASA MERRA Aerosol Reanalysis over the United States. Atmos. Environ. 2016, 125, 100-111. [CrossRef]

44. Stephens, G.L.; Vane, D.G.; Boain, R.J.; Mace, G.G.; Sassen, K.; Wang, Z.; Illingworth, A.J.; O'connor, E.J.; Rossow, W.B.; Durden, S.L. The CloudSat mission and the A-Train: A new dimension of space-based observations of clouds and precipitation. Bull. Am. Meteorol. Soc. 2002, 83, 1771-1790. [CrossRef]

45. Hunt, W.H.; Winker, D.M.; Vaughan, M.A.; Powell, K.A.; Lucker, P.L.; Weimer, C. CALIPSO lidar description and performance assessment. J. Atmos. Ocean. Technol. 2009, 26, 1214-1228. [CrossRef] 
46. Winker, D.M.; Pelon, J.R.; McCormick, M.P. The CALIPSO mission: Spaceborne lidar for observation of aerosols and clouds. In Lidar Remote Sensing for Industry and Environment Monitoring III; Society of Photo Optical: Bellingham, WA, USA, 2002; pp. 1-12.

47. Winker, D.; Pelon, J.; Coakley, J.A., Jr.; Ackerman, S.; Charlson, R.; Colarco, P.; Flamant, P.; Fu, Q.; Hoff, R.; Kittaka, C. The CALIPSO mission: A global 3D view of aerosols and clouds. Bull. Am. Meteorol. Soc. 2010, 91, 1211-1230. [CrossRef]

48. Aumann, H.; Chahine, M.; Gautier, C.; Goldberg, M.; Kalnay, E.; McMillin, L.; Revercomb, H.; Rosenkranz, P.; Smith, W.; Staelin, D.; et al. AIRS/AMSU/HSB on the Aqua mission: Design, science objectives, data products, and processing systems. IEEE Trans. Geosci. Remote Sens. 2003, 41, 253-264. [CrossRef]

49. Tobin, D.C.; Revercomb, H.E.; Knuteson, R.O.; Lesht, B.M.; Strow, L.L.; Hannon, S.E.; Feltz, W.F.; Moy, L.A.; Fetzer, E.J.; Cress, T.S. Atmospheric Radiation Measurement site atmospheric state best estimates for Atmospheric Infrared Sounder temperature and water vapor retrieval validation. J. Geophys. Res. Atmos. 2006, 111. [CrossRef]

50. Mann, H.B. Nonparametric tests against trend. Econom. J. Econom. Soc. 1945, 13, 245-259. [CrossRef]

51. Kendall, M.G. Rank Correlation Methods; The Griffin: London, UK, 1948.

52. Pal, I.; Al-Tabbaa, A. Trends in seasonal precipitation extremes-An indicator of 'climate change' in Kerala, India. J. Hydrol. 2009, 367, 62-69. [CrossRef]

53. Sneyers, R. On the Statistical Analysis of Series of Observations; World Meteorological Organization (WMO): Geneva, Switzerland, 1991.

54. Mosmann, V.; Castro, A.; Fraile, R.; Dessens, J.; Sanchez, J.L. Detection of statistically significant trends in the summer precipitation of mainland Spain. Atmos. Res. 2004, 70, 43-53. [CrossRef]

55. Adarsh, S.; Janga Reddy, M. Trend analysis of rainfall in four meteorological subdivisions of southern India using nonparametric methods and discrete wavelet transforms. Int. J. Climatol. 2015, 35, 1107-1124. [CrossRef]

56. Verhegghen, A.; Eva, H.; Ceccherini, G.; Achard, F.; Gond, V.; Gourlet-Fleury, S.; Cerutti, P.O. The potential of Sentinel satellites for burnt area mapping and monitoring in the Congo Basin forests. Remote Sens. 2016, 8 , 986. [CrossRef]

57. Koutsias, N.; Xanthopoulos, G.; Founda, D.; Xystrakis, F.; Nioti, F.; Pleniou, M.; Mallinis, G.; Arianoutsou, M. On the relationships between forest fires and weather conditions in Greece from long-term national observations (1894-2010). Int. J. Wildland Fire 2013, 22, 493-507. [CrossRef]

58. Bedia, J.; Herrera, S.; Gutiérrez, J.M.; García, S.H. Assessing the predictability of fire occurrence and area burned across phytoclimatic regions in Spain. Nat. Hazards Earth Syst. Sci. 2014, 14, 53-66. [CrossRef]

59. Barlow, J.; Peres, C.A.; Lagan, B.O.; Haugaasen, T. Large tree mortality and the decline of forest biomass following Amazonian wildfires. Ecol. Lett. 2003, 6, 6-8. [CrossRef]

60. Varma, A. The economics of slash and burn: A case study of the 1997-1998 Indonesian forest fires. Ecol. Econ. 2003, 46, 159-171. [CrossRef]

61. Cochrane, M.A. Fire science for rainforests. Nature 2003, 421, 913. [CrossRef] [PubMed]

62. Uhl, C.; Kauffman, J.B. Deforestation, fire susceptibility, and potential tree responses to fire in the eastern Amazon. Ecology 1990, 71, 437-449. [CrossRef]

63. Trollope, W. Role of fire in preventing bush encroachment in the Eastern Cape. Proc. Annu. Congr. Grassl. Soc. South. Afr. 1974, 9, 67-72. [CrossRef]

64. Snyman, H. Short-term response of the encroacher shrub Seriphium plumosum to fire. Afr. J. Range Forage Sci. 2011, 28, 65-77. [CrossRef]

65. Snyman, H. Estimating the short-term impact of fire on rangeland productivity in a semi-arid climate of South Africa. J. Arid Environ. 2004, 59, 685-697. [CrossRef]

66. Snyman, H. Short-term response in productivity following an unplanned fire in a semi-arid rangeland of South Africa. J. Arid Environ. 2004, 56, 465-485. [CrossRef]

67. Everson, C.S.; Everson, T. The long-term effects of fire regime on primary production of montane grasslands in South Africa. Afr. J. Range Forage Sci. 2016, 33, 33-41. [CrossRef]

68. Breedt, J.A.; Dreber, N.; Kellner, K. Post-wildfire regeneration of rangeland productivity and functionality-Observations across three semi-arid vegetation types in South Africa. Afr. J. Range Forage Sci. 2013, 30, 161-167. [CrossRef] 
69. Snyman, H. Short-term response of burnt grassland to defoliation in a semi-arid climate of South Africa. Afr. J. Range Forage Sci. 2006, 23, 1-11. [CrossRef]

70. La Rosa, N.S.-D.; González-Cardoso, G.; Figueroa-Lara, J.D.J.; Gutiérrez-Arzaluz, M.; Octaviano-Villasana, C.; Ramírez-Hernández, I.F.; Mugica-Álvarez, V. Emission factors of atmospheric and climatic pollutants from crop residues burning. J. Air Waste Manag. Assoc. 2018, 68, 849-865. [CrossRef] [PubMed]

71. Adeyolanu, O.D.; Are, K.S.; Oluwatosin, G.A.; Ayoola, O.T.; Adelana, A.O. Evaluation of two methods of soil quality assessment as influenced by slash and burn in tropical rainforest ecology of Nigeria. Arch. Agron. Soil Sci. 2013, 59, 1725-1742. [CrossRef]

72. Liousse, C.; Guillaume, B.; Grégoire, J.M.; Mallet, M.; Galy, C.; Pont, V.; Akpo, A.; Bedou, M.; Castera, P.; Dungall, L.; et al. Updated African biomass burning emission inventories in the framework of the AMMA-IDAF program, with an evaluation of combustion aerosols. Atmos. Chem. Phys. 2010, 10, 9631-9646. [CrossRef]

73. Suman, D. Biomass burning in North Africa and its possible relationship to climate change in the mediterranean basin. In The Impact of Desert Dust Across the Mediterranean; Springer: Berlin, Germany, 1996; pp. 113-122.

74. Reid, J.; Koppmann, R.; Eck, T.; Eleuterio, D. A review of biomass burning emissions part II: Intensive physical properties of biomass burning particles. Atmos. Chem. Phys. 2005, 5, 799-825. [CrossRef]

75. Carslaw, K.; Boucher, O.; Spracklen, D.; Mann, G.; Rae, J.; Woodward, S.; Kulmala, M. A review of natural aerosol interactions and feedbacks within the Earth system. Atmos. Chem. Phys. 2010, 10, 1701-1737. [CrossRef]

76. Zheng, X.; Zhang, S.; Wu, Y.; Zhang, K.M.; Wu, X.; Li, Z.; Hao, J. Characteristics of black carbon emissions from in-use light-duty passenger vehicles. Environ. Pollut. 2017, 231, 348-356. [CrossRef]

77. Efe, S. Spatial distribution of particulate air pollution in Nigerian cities: Implications for human health. J. Environ. Health Res. 2008, 7, 107-116.

78. Wang, R.; Balkanski, Y.; Boucher, O.; Ciais, P.; Schuster, G.L.; Chevallier, F.; Samset, B.H.; Liu, J.; Piao, S.; Valari, M.; et al. Estimation of global black carbon direct radiative forcing and its uncertainty constrained by observations. J. Geophys. Res. Atmos. 2016, 121, 5948-5971. [CrossRef]

79. Löndahl, J.; Swietlicki, E.; Pagels, J.; Massling, A.; Boman, C.; Rissler, J.; Blomberg, A.; Sandström, T. Respiratory tract deposition of particles from biomass combustion. J. Phys. Conf. Ser. 2009, 151, 012066. [CrossRef]

80. Lin, N.-H.; Tsay, S.-C.; Maring, H.B.; Yen, M.-C.; Sheu, G.-R.; Wang, S.-H.; Chi, K.H.; Chuang, M.-T.; $\mathrm{Ou}$-Yang, C.-F.; Fu, J.S.; et al. An overview of regional experiments on biomass burning aerosols and related pollutants in Southeast Asia: From BASE-ASIA and the Dongsha Experiment to 7-SEAS. Atmos. Environ. 2013, 78, 1-19. [CrossRef]

81. Dwyer, E.; Pinnock, S.; Grégoire, J.-M.; Pereira, J. Global spatial and temporal distribution of vegetation fire as determined from satellite observations. Int. J. Remote Sens. 2000, 21, 1289-1302. [CrossRef]

82. Suzuki, M.; Kushida, H.; Dobashi, R.; Hirano, T. Effects of humidity and temperature on downward flame spread over filter paper. Fire Saf. Sci. 2000, 6, 661-669. [CrossRef]

83. Li, F.; Lawrence, D.M.; Bond-Lamberty, B. Impact of fire on global land surface air temperature and energy budget for the 20th century due to changes within ecosystems. Environ. Res. Lett. 2017, 12, 044014. [CrossRef]

84. Turco, M.; Levin, N.; Tessler, N.; Saaroni, H. Recent changes and relations among drought, vegetation and wildfires in the Eastern Mediterranean: The case of Israel. Glob. Planet. Chang. 2017, 151, 28-35. [CrossRef]

85. Kutiel, H. Weather conditions and forest fire propagation-The case of the carmel fire, December 2010. Isr. J. Ecol. Evol. 2012, 58, 113-122.

86. Mehta, M.; Singh, R.; Singh, A.; Singh, N. Recent global aerosol optical depth variations and trends-A comparative study using MODIS and MISR level 3 datasets. Remote Sens. Environ. 2016, 181, 137-150. [CrossRef]

87. Roberts, G.; Wooster, M.; Lagoudakis, E. Annual and diurnal african biomass burning temporal dynamics. Biogeosciences 2009, 6, 849-866. [CrossRef]

88. Cowie, S.M.; Knippertz, P.; Marsham, J.H. Are vegetation-related roughness changes the cause of the recent decrease in dust emission from the Sahel? Geophys. Res. Lett. 2013, 40, 1868-1872. [CrossRef]

89. Dardel, C.; Kergoat, L.; Hiernaux, P.; Mougin, E.; Grippa, M.; Tucker, C. Re-greening Sahel: 30 years of remote sensing data and field observations (Mali, Niger). Remote Sens. Environ. 2014, 140, 350-364. [CrossRef] 
90. Olsson, L.; Eklundh, L.; Ardö, J. A recent greening of the Sahel-Trends, patterns and potential causes. J. Arid Environ. 2005, 63, 556-566. [CrossRef]

91. Collins, J.M. Temperature variability over Africa. J. Clim. 2011, 24, 3649-3666. [CrossRef]

92. Serdeczny, O.; Adams, S.; Baarsch, F.; Coumou, D.; Robinson, A.; Hare, W.; Schaeffer, M.; Perrette, M.; Reinhardt, J. Climate change impacts in Sub-Saharan Africa: From physical changes to their social repercussions. Reg. Environ. Chang. 2017, 17, 1585-1600. [CrossRef]

93. Ritchie, H.; Roser, M. $\mathrm{CO}_{2}$ and Greenhouse Gas Emissions. Our World Data, 2017. Available online: https://ourworlddata.org/co2-and-other-greenhouse-gas-emissions (accessed on 13 November 2019).

94. Kumar, K.R.; Sivakumar, V.; Yin, Y.; Reddy, R.; Kang, N.; Diao, Y.; Adesina, A.J.; Yu, X. Long-term (2003-2013) climatological trends and variations in aerosol optical parameters retrieved from MODIS over three stations in South Africa. Atmos. Environ. 2014, 95, 400-408. [CrossRef]

95. Kelly, L.; Brotons, L. Using fire to promote biodiversity. Science 2017, 355, 1264-1265. [CrossRef] [PubMed]

96. Jeong, G.-R.; Wang, C. Climate effects of seasonally varying Biomass Burning emitted Carbonaceous Aerosols (BBCA). Atmos. Chem. Phys. 2010, 10, 8373-8389. [CrossRef]

97. Giglio, L.; Csiszar, I.; Justice, C.O. Global distribution and seasonality of active fires as observed with the Terra and Aqua Moderate Resolution Imaging Spectroradiometer (MODIS) sensors. J. Geophys. Res. Biogeosci. 2006, 111. [CrossRef]

98. Mao, K.; Ma, Y.; Xia, L.; Chen, W.Y.; Shen, X.; He, T.; Xu, T. Global aerosol change in the last decade: An analysis based on MODIS data. Atmos. Environ. 2014, 94, 680-686. [CrossRef]

(C) 2019 by the authors. Licensee MDPI, Basel, Switzerland. This article is an open access article distributed under the terms and conditions of the Creative Commons Attribution (CC BY) license (http://creativecommons.org/licenses/by/4.0/). 